\title{
Settlement, landscape and land-use change at a Pictish Elite Centre: Assessing the palaeoecological record for economic continuity and social change at Rhynie in NE Scotland

\author{
Samantha E Jones, ' (D) Nick Evans,' Antonio Martínez Cortizas, ${ }^{2}$ (D) \\ Tim M Mighall ${ }^{3}$ and Gordon Noble'
}

\begin{abstract}
The first millennium AD was a transformative period when many of the medieval kingdoms of Europe began to take shape, but despite recent advances in palaeoecological and archaeological research there remains a shortage of interdisciplinary collaborative research targeting this period. For some regions we know relatively little about the societies who lived during this formative period. This current investigation focusses on an early medieval elite centre near to Rhynie in NE Scotland; an important power-centre during the fourth-seventh centuries AD as evidenced by a remarkable series of Class I Pictish symbol stones, fortified enclosures at Cairn more, Tap o' Noth and the Craw-Stane, as well as high status metal-working and a range of continental imports from the Craw-Stane enclosure. However, by the end of the seventh century AD, elite focus appears to have shifted elsewhere with the CrawStane and Cairn More enclosures all being abandoned. By combining paleoenvironmental analysis with available historical and archaeological archives this paper provides new insights into societal change during the first Millennium AD, with focus on the economic, social and environmental impacts caused by the rise and subsequent abandonment of elite nodes of power. A calibrated age of AD 260-4I5, near the base of the core, coincides with the earliest dates for the Craw-Stane complex and pre-dates the construction of the nearby Cairn More enclosure. The results provide a rare snapshot of the Late Roman Iron Age to Medieval environment of Northeast Scotland. This centre appears to have been supported by a rich agricultural landscape, with evidence of pastoral and arable farming, and potential metal working. One of the most significant findings of this study has revealed that despite abandonment of these elite enclosed sites by the seventh century AD, people continued to utilise the surrounding landscape and available resources right through until modern times.
\end{abstract}

\section{Keywords}

archaeology, early medieval, farming, geochemistry (XRF), NE Scotland, Pictland, pollen

Received 19 April 2020; revised manuscript accepted 4 January 2021

\section{Introduction}

The first millennium AD in northern Europe is still a dark age in terms of our understanding of Late Roman and post-Roman societies, with few written sources and an archaeological record that has been traditionally lacking in evidence. This is particularly true of the Picts in Scotland. First mentioned in late Roman-period sources, the Picts inhabited north-eastern Scotland until the late first millennium AD with the region dominated by a powerful Pictish over-kingship from at least the late seventh century AD onwards (Fraser, 2009). Pictish power centres of this period were generally thought to have been focused on the construction of hillforts on craggy knolls and hills (e.g. Alcock et al., 1989; Woolf, 2007). However, excavations at the Craw Stane in Rhynie, Aberdeenshire, from 2011 to 2017 have revealed a type of Pictish site largely unknown - the first major non-hillfort secular elite site investigated in detail in Pictland which was occupied from the late fourth century until the mid-sixth century AD (Noble et al., 2013, 2019a). Place-name analysis suggests an early form of the Rhynie name may have been rìgonin or rigonin, a 'place of, or associated with, a great king' (Noble et al., 2019a: 61).
The Craw Stane complex was first identified through aerial photography in 1978 when a series of ditched and palisaded enclosures were recognised around the in situ Class I Pictish stone, known as the Craw Stane, in the fields of Barflat farm just to the south of the current village of Rhynie. In 1977 the striking Rhynie Man Pictish stone was found in the same field only metres downslope from the Craw Stane. Class I stones mostly predate the arrival of Christianity and may have been erected as early as the

\footnotetext{
'Department of Archaeology, University of Aberdeen, UK

${ }^{2}$ EcoPast (GI-I553), Faculty of Biology, Universidade de Santiago de Compostela, Spain

${ }^{3}$ Department of Geography and Environment, University of Aberdeen, UK

Corresponding author:

Samantha E Jones, Department of Archaeology, School of Geosciences, University of Aberdeen, St. Mary's, Elphinstone Road, Aberdeen, AB24 3UF, UK.

Email: samantha.jones@abdn.ac.uk
} 
fourth century AD (Noble and Evans, 2019). These stones are often decorated with incised images on one side, with symbols consisting of abstract shapes and animals. Class II stones contain similar symbols to Class I as well as Christian motifs such as the cross and liturgical scenes and appear mainly around the seventh century AD (Allen and Anderson, 1903; Noble and Evans, 2019). Only Class I stones are found at Rhynie. The Craw Stane and Rhynie Man are two of eight Class I stones known from Rhynie in two notable concentrations. A second concentration is found around $0.7 \mathrm{~km}$ to the north where three other Pictish stones have been found in the location of a contemporary cemetery containing two square barrows and the skeleton of a female individual, also contemporary with the settlement complex excavated at the Craw Stane (Mitchell and Noble, 2017; Noble et al., 2019a). The Craw Stane complex comprised two ditched enclosures that were replaced by a complex wooden enclosure wall with a wall-walk made of oak posts and planks. Inside were at least two large wooden buildings and settlement extended outside the complex. The Craw Stane and the Rhynie Man stood at the entrance of the earlier ditched complex and near to one of the buildings inside (Noble et al., 2013, 2019a). More than 30 radiocarbon dates allow a well constrained chronology for the site with dated activity at the Craw Stane complex beginning in the period cal AD 330-390. Activity took place over a period of 100-225 years and dated activity at the complex ended in cal AD 480-570 (all quoted at 95\% probability) (Noble et al., 2019a).

Since 2017 the University of Aberdeen has been investigating the wider environs of the upper Strathbogie valley, funded by Historic Environment Scotland, and have found two further, broadly contemporary, early medieval sites; Cairn More and Tap O' Noth. Previous keyhole excavations at Cairn More by Murray Cook as part of the Strathdon hillforts project identified a fifth and sixth century AD phase of activity (Cook, 2013). Two brooch moulds and a pin mould were recovered from the foundation cut of the middle rampart and are likely to be early medieval in origin as well (Cook et al., 2010). More recent excavations (2018-2019) conducted by the University of Aberdeen has produced 13 further radiocarbon dates (from a range of charcoal samples comprising alder, birch, willow and hazel) which not only confirmed the fifth and sixth century AD phase of occupation, but suggested that like the Craw Stane complex the ringfort was first constructed in the fourth century $\mathrm{AD}$ and went out of use in the seventh century $\mathrm{AD}$ (a century or so after abandonment of the Craw Stane enclosure) (Noble et al., 2019c).

Tap o' Noth is Scotland's second highest hillfort (563 m OD). The complexity of the fort at Tap o' Noth and the hundreds of hut platforms associated with the site (Halliday, 2007; Ralston and Watt, 1981, 1982, 1983), suggests it may also have been an elite centre of considerable importance. Originally the fort was assumed to be prehistoric in date and indeed 2017-2018 excavations by the University of Aberdeen confirmed fourth- first century BC construction and activity on the summit enclosure (Noble et al., 2019d). However, during the 2019 excavations of the lower fort enclosure and some of the hut platforms, radiocarbon dating produced dates from the third to late sixth century AD. The dates are largely contemporary with the Craw Stane enclosure albeit with a slightly earlier construction and slightly later abandonment date (Noble et al., pers comm). Excavations are ongoing and future work may alter the chronological range for activity at Tap o' Noth.

While all three enclosed sites are unusual and rare examples of settlement from this time period, the character of the evidence from the lowland site at the Craw Stane suggests a particular significance. The artefact assemblage from the Craw Stane complex is extensive with more than 1000 artefacts recovered over five seasons of excavation, despite the plough-truncated nature of the site (Noble et al., 2019b). Finds include pottery, glass, metalwork and evidence for non-ferrous metalwork production. Particularly notable are the imports of Mediterranean and continental origin which are found at other elite centres in Britain and Ireland (only some of which are documented in early sources). The Mediterranean imports are the first identified at a Pictish site and include sherds of late Roman-period amphorae of late fifth- or early sixthcentury $\mathrm{AD}$ date. Continental imports include sherds of glass from western France. The metalworking assemblage comprises evidence for the production of hand-pins and other pin forms in iron, bronze and probably silver, penannular brooches and a range of other objects (Noble et al., 2019a).

Despite the wealth of archaeological data obtained from the Craw Stane complex we still know very little about the day-to-day life of the early medieval people in this valley and why the Craw Stane complex was abandoned in the sixth century AD and the Cairn More settlement in the seventh century AD. The purpose of this paper is to chart the development of the landscape and economy during and after the establishment and seeming abandonment of the enclosures at the Craw Stane and Cairn More (work at Tap o' Noth is ongoing) to better understand Pictish landscape and land-use from the Late Roman to Medieval period. Multi-proxy palaeoenvironmental data (pollen, non-pollen-palynomorphs (NPPs) and X-ray diffraction (XRF) analysis) has been used to explore the economic, social and environmental impacts caused by the rise and subsequent abandonment of two high-status enclosure complexes near to the coring location - Craw Stane and Cairn More. Using a combined palaeoecological approach and comparing the results with both historical and archaeological archives has great potential to provide new insights into how past societies lived through, or were impacted by, environmental/social change.

\section{Background}

\section{Rhynie}

Today Rhynie is a small village in the upper Strathbogie valley of western Aberdeenshire, north-eastern Scotland (Figures 1 and 2). Rhynie is located between the Cairngorm Mountains and Cabrach Hills to the west and the Correen-Bennachie range to the east. It lies between the River Bogie and the Ord Burn at $181 \mathrm{~m}$ OD, making it one of the most elevated settlements of north-eastern Scotland. It is also set in a fertile agricultural valley with close connections to lowland areas to the east and north. It is at a crossroads of major routeways through the hills leading westwards up the Cabrach, east to Insch and the River Urie, northwards to the Moray coast, the upper reaches of the River Don to the south, and the River Dee and the Mounth beyond.

\section{Natural environment and coring location}

The geology within the valley consists predominantly of sandstone, with some incorporation of conglomerate, andesite and tuffs, whilst the surrounding hills predominantly consist of shales with cherts (Rice and Ashcroft, 2003). The soil within the vicinity of the core location consists of mineral, humus-iron podzols from fluvio-glacial and raised beach sands and gravels derived from acidic parent material, whilst the core location consists of peat. Brown soils derived from Old Red Sandstone sediments and argillaceous schists are components of the surrounding hills (National Soil Map of Scotland, 2020). The Old Statistical Accounts of Scotland (OSA) (1797) describe the soils for the Parish of Rhynie as various; loamy near the River Bogie, and stony and gravelly, yet very fertile near the bottom of the hills. Pastoral farming seems to have been the main economy with 172 horses, 882 black cattle and 2255 sheep recorded in the OSA (1797). Arable farming is described as improving but had not yet made great advances by the end of the 1700 s, although turnips may have been an important crop; turnips (10 acres) and sown grass ( 40 acres) are the only crops recorded in OSA (1797) for the parish of Rhynie. However, in the adjacent parish of Kearn, which in 


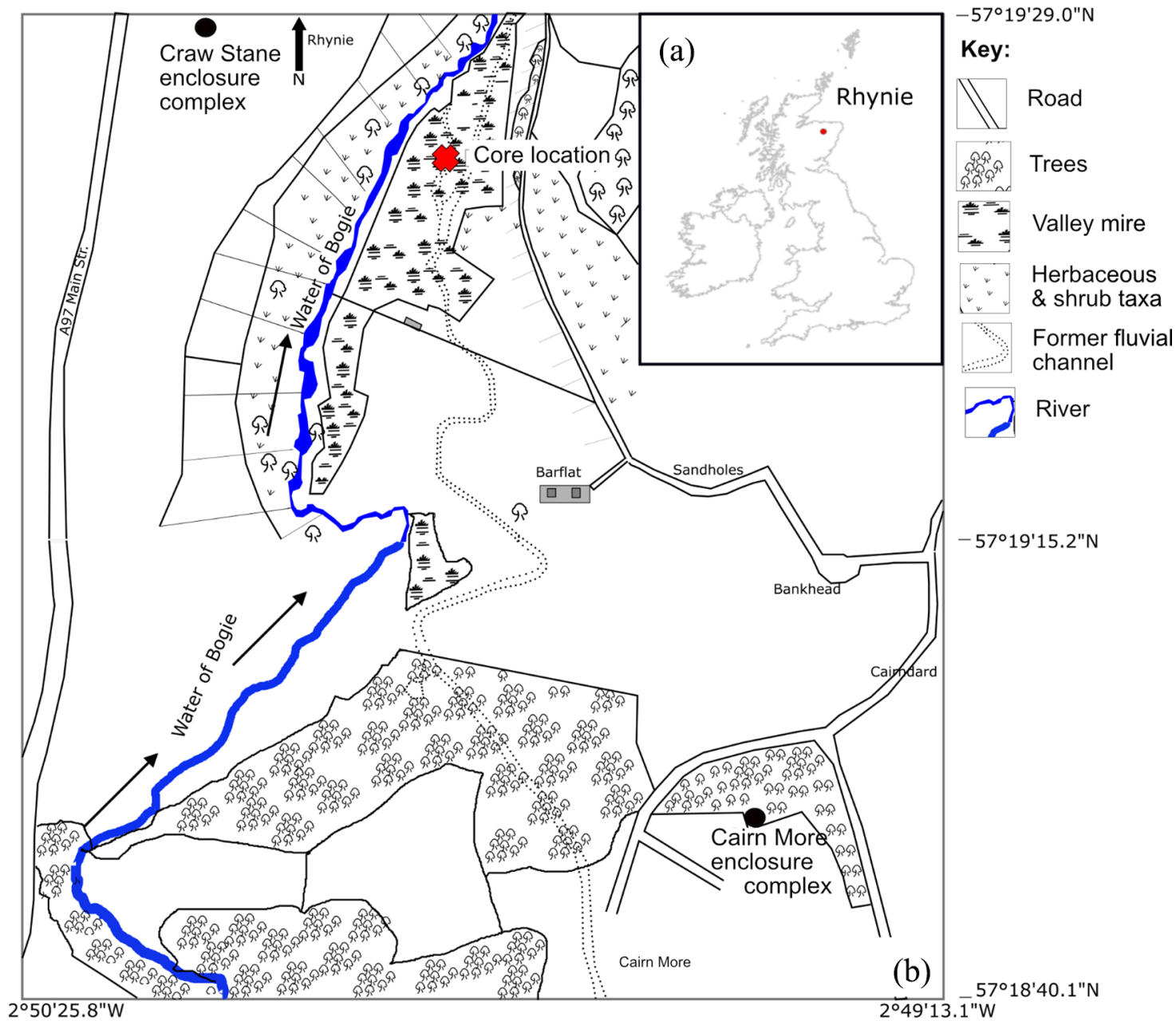

Figure I. (a) Location of study area. (b) Core location and key archaeological sites referred to in the text.

Key: dotted line: earlier water course; black circles: Pictish enclosure locations; red cross: core location; Arrows: direction of water course.

the 1700s would have included the core location (Figure 1b), the soils seem to have been more productive with a wide range of crops grown including oats, barley, potatoes, peas, turnips, other greens and cabbage (OSA, 1794). By 1845, the use of lime and waste land reclamation led to a significant increase in farming in the parish of Rhynie, with produce doubling between 1820 and 1845 (The New Statistical Accounts of Scotland (NSA), 1845). Lewis (1846) described a variety of crops grown in the locality during the 1800s, including different types of cereal, potatoes and turnips, whilst the hills and moorlands afforded good pasturage for sheep and black-cattle, and that the mosses (peat bogs) of Essie (located to the west of Rhynie) provided ample supplies of peat for fuel.

A valley mire was selected for the core location at $57^{\circ} 19^{\prime} 26.3^{\prime \prime} \mathrm{N}$ $2^{\circ} 49^{\prime} 59.3^{\prime \prime} \mathrm{W}, 900 \mathrm{~m}$ south east of the village of Rhynie and $300 \mathrm{~m}$ south-east of the enclosure complex at the Craw Stane. The enclosure at Cairn More lies approximately $1.3 \mathrm{~km}$ to the south (Figures 1 and 2). The main vegetation on the mire today is predominantly Carex (sedge) with some Sphagnum (peat moss). Poaceae (grass) dominated pastures lie adjacent to the mire, whilst along the Water of Bogie alder trees are well established. The adjacent slopes are colonised by mainly Ulex (gorse) and Pinus (pine), with some Betula (birch), Cyperaceae (sedge), Poaceae (grass) and other herbaceous species.

\section{Methods}

\section{Sample selection}

A $1.86 \mathrm{~m}$ core was extracted from the mire (Figures 1 and 2) using a Russian peat corer and stored in plastic guttering wrapped in polythene and stored in a cold store ready for laboratory analysis. The core was lithologically described and sub-sampled every $2 \mathrm{~cm}$ (sample thickness: $1 \mathrm{~cm}^{2}$ ) for pollen, NPPs, LOI and geochemical analysis (XRF). Modern sediments (post-1950) were recorded in the radiocarbon record at $89-90 \mathrm{~cm}$ (Table 1). Sediments were sub-sampled until $68 \mathrm{~cm}$; above $68 \mathrm{~cm}$ the sediments became unconsolidated and very fibrous.

\section{Laboratory preparation}

\section{- Radiocarbon analyses}

No macrofossil remains were identified in this record for radiocarbon dating. For this reason, eight peat samples (bulk sediment) were submitted to SUERC radiocarbon laboratory for radiocarbon dating. Radiocarbon ages have been calibrated using the latest CALIB 7.1 calibration program and INTCAL20 (Reimer et al., 2020; Stuiver et al., 2020). The use of bulk sediments for radiocarbon dating is not always reliable given that carbon from uncertain provenances can cause age errors (Grimm and Jacobson, 2004; Grimm et al., 2009). Only the humic acid content was measured in this investigation therefore an age slightly older or slightly younger than actual remains possible (Shore et al., 1995). However, all dates apart from at $131 \mathrm{~cm}$ are in chronological order.

To check the validity of the dates, an outlier analysis (Figure 3 ) with a prior probability set at $5 \%$ was conducted on the radiocarbon sequence using the OxCal program (Bronk Ramsey, 2009a, $2009 \mathrm{~b}$ ). This means ages with a posterior probability below $5 \%$ are considered to be reliable. One outlier was identified at $131 \mathrm{~cm}$. The 


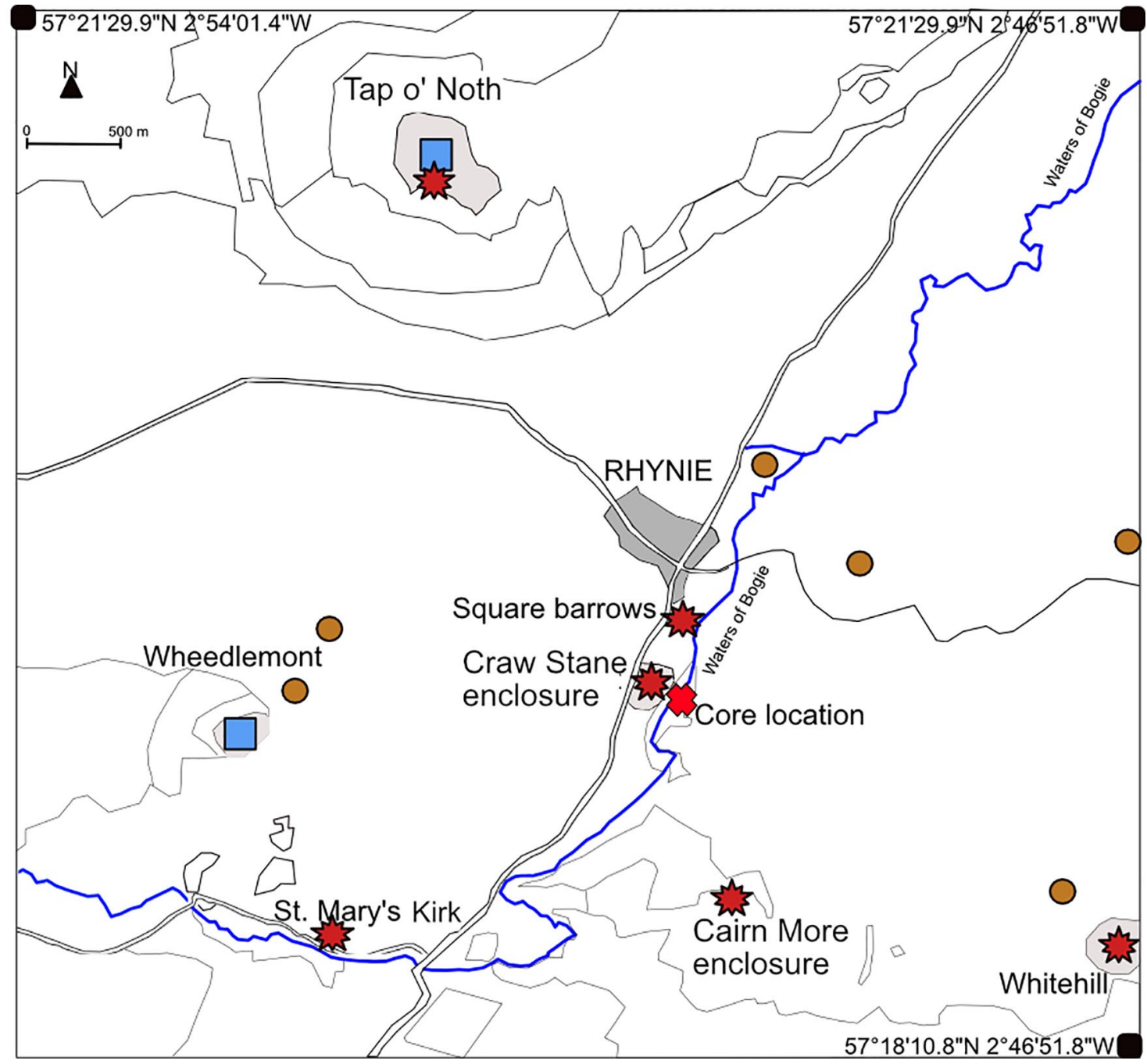

Figure 2. Map of Archaeological sites within the vicinity of the core site (Red cross). Circles represent Neolithic/Bronze Age stone circle locations. Squares represent Iron Age sites. These include Tap o' Noth and Wheedlemont hill; Stars indicate Medieval sites. These include the early medieval square barrows and enclosures at the Craw Stane, Cairn More, Tap o' Noth and potentially Whitehill; and the later Medieval sites at St Mary's Kirk at Auchindoir.

Table I. ${ }^{14} \mathrm{C}$ results from the Craw Stane mire sequence, calibrated to $2 \sigma$.

\begin{tabular}{|c|c|c|c|c|c|c|c|}
\hline Lab code & Material type & $\begin{array}{l}\text { Depth } \\
(\mathrm{cm})\end{array}$ & $\begin{array}{l}\text { Thick-ness } \\
(\mathrm{cm})\end{array}$ & ${ }^{14} \mathrm{C}$ age & Error $+1-$ & $\frac{\delta^{13} \mathrm{C}}{\%}$ & $\begin{array}{l}\text { Calibrated } \\
\text { age } A D \\
(95.4 \%)\end{array}$ \\
\hline SUERC-804I3 & Peat humic acid & 89-90 & 2 & $\begin{array}{l}\text { Fraction modern: } \\
\mathrm{I} .093 \mathrm{I} \pm 0.004\end{array}$ & Modern & -30.6 & $1957-2003$ \\
\hline SUERC-8| 223 & Peat-humic acid & $110-111$ & 2 & 593 & 21 & -30.7 & |303-1408 \\
\hline SUERC-82058 & Peat-humic acid & 125 & I & 684 & 26 & -30.2 & $127 \mid-1387$ \\
\hline SUERC-804I4 & Peat-humic acid & $|3|$ & I & 1171 & 30 & -29.5 & $770-960$ \\
\hline SUERC-82062 & Peat-humic acid & 145 & I & 944 & 26 & -29.9 & $1028-1154$ \\
\hline SUERC-8I 224 & Peat-humic acid & 156 & I & 1092 & 24 & -29.6 & $892-1011$ \\
\hline SUERC-82063 & Peat-humic acid & 167 & I & 1146 & 26 & -29.2 & $777-792$ \\
\hline SUERC-7689I & Peat-humic acid & $181-182$ & 2 & 1686 & 24 & -25 & $260-415$ \\
\hline
\end{tabular}

Poisson-process deposition model: P_Sequence was then used to produce an age-depth model (Figure 3), for the remaining six radiocarbon ages (Bronk Ramsey, 2009a, 2009b; Bronk Ramsey and Lee, 2013).

\section{- Loss-on-Ignition}

Loss-on-ignition (LOI) is used to determine the quantity of organic and mineral content in a sample and was conducted at $2 \mathrm{~cm}$ intervals between 185 and $83 \mathrm{~cm}$. Samples were dried overnight in a drying cupboard at $60^{\circ} \mathrm{C}$, weighed and burnt for $4 \mathrm{~h}$ at $550^{\circ} \mathrm{C}$ and weighed again, following the conventional methods outlined in Heiri et al. (2001). This method can help to identify natural or anthropogenic disturbance as well as potential taphonomic processes impacting the fossil pollen and NPP record.

\section{- Geochemical analysis using Emma-XRF}

Geochemical analysis was undertaken at RIAIDT (Infrastructure Network for the Support of Research and Technological 


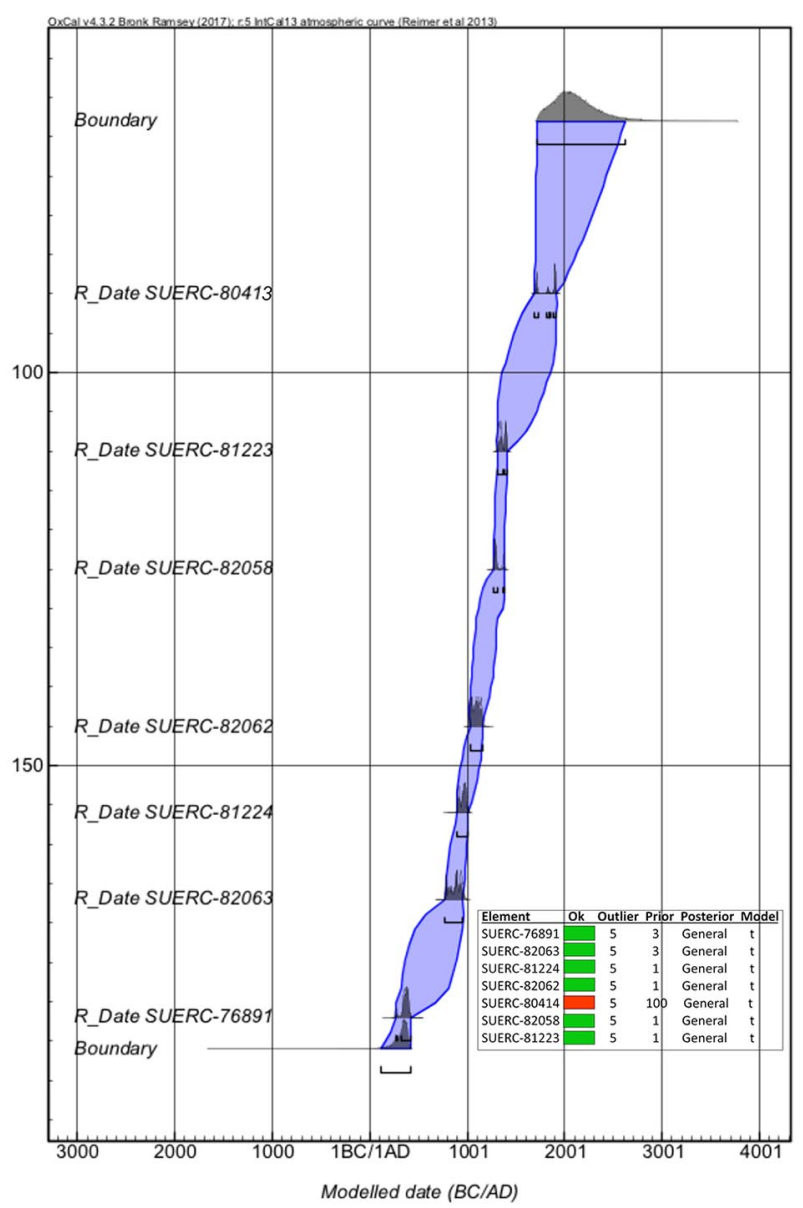

Figure 3. Bayesian age/depth model and outlier analysis from the Craw Stane mire sequence. The age/depth model uses the Poisson process deposition model of $\mathrm{P}$ _sequence, which assumes a nonlinear deposition using OxCal v4.2.4 (Bronk Ramsey, 2009a, 2009b, 2020) and IntCall 3 atmospheric curve (Reimer et al., 2013).

Development) facility of the University of Santiago de Compostela (Spain). The principle decision to undertake geochemical analysis was to detect traces of metals which might indicate a metal working economy, but this type of analysis can also detect environmental change including fluctuations in wetness/water levels and terrigenous inwash associated with natural or human initiated erosion. Concentrations of major and minor elements ( $\mathrm{Si}, \mathrm{Al}, \mathrm{Fe}, \mathrm{Ca}, \mathrm{K}, \mathrm{Ti}$ and $\mathrm{S}$ ), trace lithogenic elements ( $\mathrm{Ga}, \mathrm{Nb}$, $\mathrm{Rb}, \mathrm{Sr}, \mathrm{Ti}, \mathrm{Zr}, \mathrm{Y}$ ), trace metals/metalloids ( $\mathrm{Mn}, \mathrm{Cu}, \mathrm{Cr}, \mathrm{Zn}, \mathrm{Ni}$, $\mathrm{Pb}$, As and $\mathrm{U}$ ) and halogens (Br) were obtained by energy dispersive miniprobe multi-element X-ray fluorescence (EMMAXRF) analysis (Cheburkin and Shotyk, 1996; Weiss et al., 1998). Quantification limits were $0.001 \%$ for Ti, $0.01 \%$ for $\mathrm{Si}, \mathrm{Al}, \mathrm{Fe}$ and $\mathrm{S}, 0.5 \mu \mathrm{g} \mathrm{g}^{-1}$ for $\mathrm{Pb}, 10 \mu \mathrm{g} \mathrm{g}^{-1}$ for $\mathrm{Cr}$ and $\mathrm{Mn}$, and $1 \mu \mathrm{g} \mathrm{g}^{-1}$ for the other elements. Replicate measurements were performed on one of every five samples in order to account for reproducibility; all replicates agreed within $5 \%$.

The main geochemical signals were extracted by applying a principal component analysis (PCA) to the geochemical data set. This was performed on the correlation matrix using a varimax rotation, a solution that maximises the loadings of the variables on the components. This rotation usually provides clearer patterns, helping to identify the underlying (latent) factors affecting peat composition. PCA on the correlation matrix provides loadings for the variables that are in fact correlation coefficients and the square of a loading in a component accounts for the proportion of variance of a variable allocated into that component. The sum of the squares of the loadings of the extracted components is the communality of the variable (i.e. the total proportion of its variation explained by the

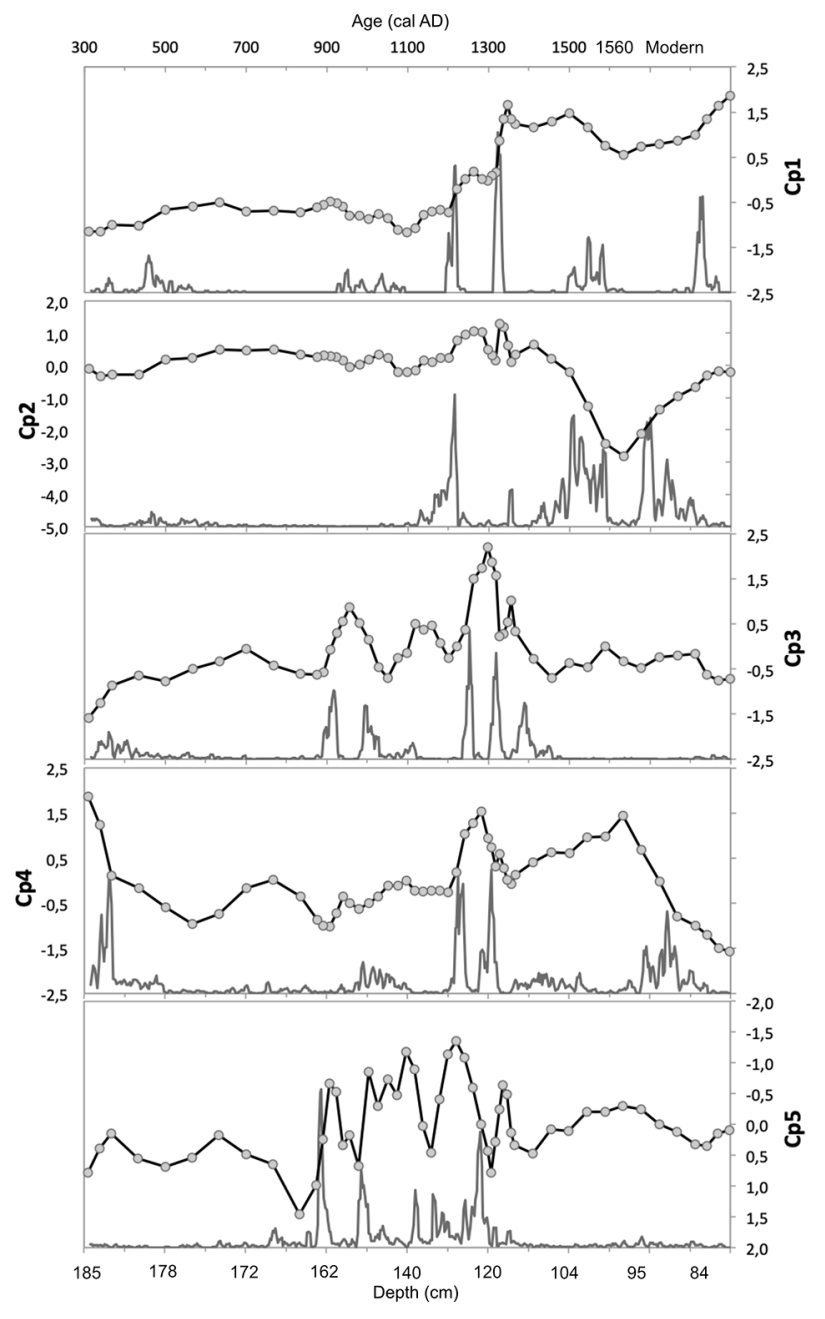

Figure 4. Chronology of the changes of the scores of the five principal components ( $\mathrm{Cpl}-\mathrm{Cp}_{\mathrm{p}}$ ) extracted (line with symbols). The line without symbols corresponds to the probability of a change point in the record.

components). This can be depicted as a simple but informative cumulative graph (see e.g. Küttner et al., 2014; Muller et al., 2008; Schofield et al., 2010), as shown below (Figure 4).

To detect discrete changes occurring in the age-depth records the change point modelling (CP) routine was used, developed by Gallagher et al. (2011) and applied in previous investigations on peat records (e.g. Kylander et al., 2013). The approach uses transdimensional Markov chain Monte Carlo to sample thousands of possible solutions, in a Bayesian context, balancing the requirement of fitting the data and avoiding unjustified complexity on the change-point structure.

\section{- Pollen and NPPs}

Pollen and non-pollen palynomorph (NPPs) analysis allows us to reconstruct past vegetation communities and is particularly useful at helping us to better understand past agricultural economies, landscape change, abandonment or continuity. Pollen and NPP samples were prepared using the conventional methods outlined in Moore et al. (1991), including the additional step of density separation (Nakagawa et al., 1998). A representative minimum sum of 500 total land pollen (TLP) (cf. Birks and Birks, 1980) was counted for all sub-samples where possible. Identification was aided by reference keys in Fægri et al. (1989), Moore et al. (1991), Beug (2004) and Reille (1999), and supported by a modern type-slide reference collection housed at the University of Aberdeen. Since Myrica and Corylus are difficult to separate 
(Edwards, 1981), these species have been grouped as Corylus avellana-type.

In terms of cereal pollen identification, some wild grasses produce considerably larger pollen grains (e.g. Bromus, Elymus, Ammophilla, Glyceria, Leymus) which can overlap with the measurements of Hordeum vulgare (e.g. Albert and Innes, 2019; Andersen, 1979; Beug, 1961; Dickson, 1988; Fægri and Iversen, 1975; Joly et al., 2007). Most of these wild grasses, however, are lowland or coastal grasses. The only problematic grass likely to be present at Rhynie is Glyceria fluitans, native to upland regions of the UK and indicative of reed swamp and fen communities (Albert and Innes, 2019; Rodwell, 1995). Some authors have demonstrated that Glyceria fluitans is generally smaller than $40 \mu \mathrm{m}$ in long diameter (when mounted in silicone oil) with a large average pore annulus diameter of $9.5-10 \mu \mathrm{m}$ (Albert and Innes, 2019; Andersen, 1979; Fægri and Iversen, 1975). The long diameter of Hordeum vulgare is problematic in that it can overlap with Glyceria fluitans between 32 and $40 \mu \mathrm{m}$ but Hordeum vulgare can also be much larger (up to $\sim 47 \mu \mathrm{m}$ ). The annulus diameter of Hordeum vulgare also tends to be smaller than that of Glyceria fluitans $(7.5-9 \mu \mathrm{m})$ (Albert and Innes, 2019; Andersen, 1979; Fægri and Iversen, 1975). In this investigation it has not been possible to separate wild Poaceae from Hordeum vulgare for pollen grains smaller than $40 \mu \mathrm{m}$. Only Poaceae pollen with a long diameter $40 \mu \mathrm{m}+$ and an annulus diameter of $8 \mu \mathrm{m}+$ (Andersen, 1979; Beug, 2004; Dickson, 1988; Moore et al., 1991) have been recorded as cereal types. In addition to the cereal type counts, detailed biometric measurements were recorded on a selection of 95 cereal pollen types from four sample depths, between 185 and $180 \mathrm{~cm}$. The samples selected span the main Craw Stane enclosure period before its abandonment.

Standards of pollen preservation were assessed in order to better understand the taphonomic processes influencing pollen representation. Damaged pollen grains have been divided into four main categories (see Figure 7b), adapted from Cushing (1967), Delcourt and Delcourt (1980), and Tipping (1987). Categories include broken, crumpled, corroded-identifiable and corrodedunidentifiable. Broken and crumpled categories would have been influenced by mechanical processes, such as breakage during transport, whilst corroded grains would have been subject to chemical weathering, such as oxidation (Cushing, 1967; Delcourt and Delcourt, 1980). The pollen and spore data are expressed as a percentage of total land pollen (TLP), with spores, aquatics and local mire taxa (Cyperaceae and Filipendula) excluded from the sum. This has been done in order to see anthropogenic indicators more clearly in the pollen record which may otherwise have been supressed by the local taxa growing on the mire. NPPs were also counted during routine pollen analysis and were identified using information from Bakker and van Smeerdijk (1982), Van Geel (1976, 1978), Van Geel et al. (1981, 1983, 1986), Haaster (1984), Kuhry (1985, 1997), Pals et al. (1980) and Van der Wiel (1983).

Originally the NPPs were calculated as percentages but this resulted in an over representation of spore producing fungi and an under representation of other NPPs. To provide a more accurate representation of individual NPPs it was therefore decided to express these as concentrations. Microscopic charcoal particles greater than $5 \mu \mathrm{m}$ in length were counted and are represented as total frequency of charcoal relative to the 500 pollen count. The pollen diagrams were constructed and delineated using CONISS software as part of the Tilia and Tilia.graph version 1.7.16 package (Grimm, 1991-2011).

\section{Results}

\section{Chronology}

Radiocarbon ages are presented in Table 1 and an OxCal agedepth model in Figure 3. The bottom of the core (at 181-182 cm) produced an age range of AD 260-415 (95.4\% confidence), which coincides with the beginning of the Craw Stane complex. The results identified sample number SUERC-80414 at $131 \mathrm{~cm}$ as an outlier with a posterior probability of $100 \%$. This date coincides with a peak in Potamogeton, Spirogyra and Glomus cf. fasciculatum and a dip in LOI, which suggests the cause of the outlier was likely a brief in-wash event of older carbon possibly due to a flood event. All other radiocarbon ages are in chronological order. The age/depth graph (Figure 3) displays a tight error range; the modelled ages are therefore considered reliable and have thus been applied to the pollen and NPP data (Figures 6 and 7). A possible hiatus is represented above $102 \mathrm{~cm}$ where radiocarbon ages jump from AD 1303 to 1408 at $110-111 \mathrm{~cm}$ to post 1950 at $89-90 \mathrm{~cm}$, although despite a transition in the lithology at $98 \mathrm{~cm}$ (Table 2), there is no evidence for an abrupt transition in pollen (Figure 7). Given the fibrous nature of sediments above $98 \mathrm{~cm}$ the modern age may well be due to root penetration that has pushed younger material downwards.

\section{Stratigraphy and loss-on-ignition (LOI)}

The stratigraphy and LOI is represented in Table 2 and Figure 7

\section{Geochemical analysis (XRF)}

Principal Component Analysis (PCA) was undertaken on the geochemical results from the XRF to better understand the different environmental/anthropogenic factors impacting the chemical elements. Principal component analysis extracted five components (Cp1-Cp5) that account for $88 \%$ of total variance of the geochemical data set. Loadings for the elements can be found in Table 3 and the fractionation of communalities in Supplemental Material 3. The first component, $\mathrm{Cp} 1$ (41\% of variance), shows positive loadings for markers of total organic matter (OM) content (LOI), biophyle elements $(\mathrm{S}, \mathrm{Ca})$, metals and halogens that bind preferentially to $\mathrm{OM}(\mathrm{Pb}, \mathrm{Zn}, \mathrm{Cu}, \mathrm{As}, \mathrm{Ni}, \mathrm{Fe}$ and $\mathrm{Br}$ ), whilst negative loadings correspond to typical lithogenic elements ( $\mathrm{Si}, \mathrm{Al}, \mathrm{Sr}, \mathrm{Zr}, \mathrm{K}$ and $\mathrm{Nb}$ ). This component reflects the balance between $\mathrm{OM}$ and mineral matter (MM) content of the peat. The data shows seven main changepoints (Figure 4), delimiting eight phases in the evolution of the mire. High MM content prior to c. AD 360, an increase in OM content from c. AD 460 to 510, remaining almost stable until c. AD 930-950 when a small decrease in OM occurred; by c. AD 1220 there was a rapid increase in OM, followed by another sharp increase by c. AD 1320. OM content remained at is highest until c. AD 1510, when another slight decrease occurred to c. AD 1580, then it remains stable until c. AD 1825 when OM then increased continuously until recent times.

The second component, Cp2 (26\% of the variance), shows positive loadings for lithogenic elements ( $\mathrm{Rb}, \mathrm{Ti}, \mathrm{Ga}, \mathrm{K}, \mathrm{Nb}, \mathrm{Y}$, $\mathrm{Al}, \mathrm{Si}$ ) and negative loadings for $\mathrm{Ca}$ and $\mathrm{S}$ (Table 3 ). This seems to be a signal related to a change in mineralogy, as the elements with positive loadings are typical of felsic/acid mineralogy (as granitic rocks) while the negative loadings may point to a calcic source. The increase of $\mathrm{S}$ together with small increases in total OM (20\% of the variance of LOI, Table 3 and Figure 4$)$ and $\mathrm{Br}$ ( $11 \%$ of its variance, Table 3 and Figure 4 ) indicates that small OM changes were also involved in changing source: as the calcic signal increased the OM content also increased slightly. Although a minor increase in lithogenics is seen around c. AD 460 (Figure 4), $\mathrm{Cp} 2$ scores show little variation until c. AD 1215 when two small peaks occur (c. AD 1215-1290 and around c. AD 1350). But the most intense change, representing an increase of the calcic signal, starts by c. AD 1505 and reaches its maximum negative values of the entire record between c. AD 1570 and 1680, after that returning slowly to values closer to zero.

The third principal component ( $9 \%$ of the variance) is dominated by $\mathrm{Cr}$ with moderate to low contributions $(20-37 \%$ of their 
Table 2. Stratigraphy and LOI from the Craw Stane mire.

\begin{tabular}{ll}
\hline $98-0 \mathrm{~cm}:$ & Dark brown fibrous reed swamp peat. LOI drops to $33 \%$ at $94 \mathrm{~cm}$ followed by a pronounced increase in organic matter (to I00\%) \\
between 92 and $86 \mathrm{~cm}$, followed by a decline to $83 \%$ at $83 \mathrm{~cm}$.
\end{tabular}

Table 3. Loadings of the chemical elements and LOI in the five components extracted with PCA from the Craw Stane mire.

\begin{tabular}{lrrrrr}
\hline & \multicolumn{1}{c}{ CpI } & \multicolumn{1}{c}{$C_{p 2}$} & \multicolumn{1}{c}{$C_{p 3}$} & \multicolumn{1}{c}{$C_{p 4}$} & \multicolumn{1}{c}{$C_{p 5}$} \\
\hline $\mathbf{P b}$ & 0.93 & -0.20 & 0.08 & 0.09 & 0.01 \\
$\mathbf{B r}$ & 0.90 & -0.34 & 0.08 & 0.04 & 0.00 \\
$\mathbf{Z n}$ & 0.88 & -0.18 & 0.13 & 0.18 & 0.09 \\
$\mathbf{C u}$ & 0.88 & -0.02 & 0.21 & 0.31 & -0.04 \\
$\mathbf{L O I}$ & 0.87 & -0.45 & 0.04 & 0.13 & 0.00 \\
$\mathbf{A s}$ & 0.85 & -0.36 & 0.09 & 0.21 & -0.05 \\
$\mathbf{S}$ & 0.70 & -0.65 & 0.04 & 0.23 & -0.06 \\
$\mathbf{N i}$ & 0.63 & -0.13 & 0.61 & 0.30 & 0.07 \\
$\mathbf{F e}$ & 0.62 & 0.05 & 0.46 & 0.54 & 0.11 \\
$\mathbf{Z r}$ & -0.64 & 0.18 & -0.04 & 0.05 & -0.64 \\
$\mathbf{A l}$ & -0.66 & 0.60 & 0.16 & -0.15 & 0.11 \\
$\mathbf{S i}$ & -0.75 & 0.57 & 0.02 & -0.20 & 0.07 \\
$\mathbf{S r}$ & -0.81 & 0.33 & 0.11 & 0.25 & -0.14 \\
$\mathbf{R b}$ & -0.05 & 0.85 & 0.14 & 0.17 & -0.22 \\
$\mathbf{T i}$ & -0.36 & 0.85 & 0.13 & 0.03 & 0.14 \\
$\mathbf{G a}$ & -0.25 & 0.83 & 0.10 & 0.35 & 0.08 \\
$\mathbf{K}$ & -0.60 & 0.75 & 0.04 & -0.11 & -0.05 \\
$\mathbf{N b}$ & -0.51 & 0.63 & 0.28 & 0.01 & 0.22 \\
$\mathbf{Y}$ & 0.28 & 0.56 & 0.53 & 0.37 & 0.06 \\
$\mathbf{C a}$ & 0.56 & -0.69 & -0.04 & 0.12 & 0.06 \\
$\mathbf{C r}$ & 0.01 & 0.30 & 0.89 & 0.06 & 0.05 \\
$\mathbf{U}$ & 0.29 & 0.13 & 0.14 & 0.86 & 0.03 \\
$\mathbf{M n}$ & -0.29 & 0.46 & 0.29 & 0.32 & 0.54 \\
\hline & & & & &
\end{tabular}

respective variance) from $\mathrm{Ni}, \mathrm{Fe}$ and $\mathrm{Y}$ (Table 3, Figure 4). This is clearly a metal enrichment signal. Apart from an early small increase in these metals by c. AD 360 and a small decrease since the beginning of the c. AD 1800 s, the record is characterised by three main peaks occurring by c. AD 920-990, c. AD 1110-1180, c. AD 1240-1320 and a smaller peak c. AD 1340-1390 (Figure 4).

The fourth component, $\mathrm{Cp} 4$ ( $8 \%$ of the variance), again represents a metal signal dominated by $U$ with small contributions (10$29 \%$ of their respective variance) from $\mathrm{Fe}, \mathrm{Ni}, \mathrm{Mn}, \mathrm{Ga}$ and $\mathrm{Y}$ (Table 3 and Figure 4). The record of scores is characterised by elevated values at the base, until c. AD 360, predominantly negative or close to zero values until c. AD 1200 when a rapid increase occurs and lasts for a century (until c. AD 1310), declining thereafter; by c. AD 1360 scores increase again reaching a second maximum by c. AD 1650, then decline rapidly from c. AD 1690 until recent times (with a slight reduction in the rate of change by c. AD 1740).

Cp5 (4\% of the variance) reflects the inverse relationship between $\mathrm{Zr}$ (negative loading) and $\mathrm{Mn}$ (moderate positive loading) (Table 3 and Figures 4 and 5). Both elements load in other components as well, so Cp5 may reflect a process that is not involved with the total content of mineral matter ( $\mathrm{Cp} 1)$, mineralogical changes $(\mathrm{Cp} 2)$ or metal signals $(\mathrm{Cp} 4)$. Manganese is well known for its redox-sensitive behaviour, tending to be depleted in anoxic conditions and enriched under oxidising conditions. While $\mathrm{Zr}$ is an element that is hosted almost exclusively in zircons, heavy, small grain size (usually silt size) (Taboada et al., 2006) and highly resistant minerals that concentrate after erosion and sedimentation processes. Our interpretation of the inverse variation of both elements is that they may reflect episodes of enhanced runoff and soil erosion: increased runoff may imply a rise in the water table of the mire, with anoxic conditions causing a depletion of Mn. At the same time, increased runoff would provide a larger input of mineral matter (and zircons) to the mire. As will be discussed later, the charcoal record lends support to this interpretation (Figure 5). The record of $\mathrm{Cp} 5$ scores shows a see-saw pattern between c. AD 770 and c. AD 1350, with four major increases in $\mathrm{Zr}$ concentration by c. AD 880-930, 980-1120, 1190-1280 and 1314-1350. Minor increases are also detected at c. AD 370, 580 630 and $1500-1670$.

\section{Pollen and non-pollen palynomorph results}

Palynomorph results have been divided into three main zones based on CONISS. Zone 1 has been further divided into subzones $1 \mathrm{a}$ and $1 \mathrm{~b} ; 1 \mathrm{~b}$ is a transitional zone between zones 1 and 2 (Figures 6 and 7).

Zone 1a (186-164 cm) AD 220-800 (Grey-brown organic silty clay)

A significant proportion of zone 1a is represented by arboreal taxa. These taxa may have been growing on the adjacent free draining slopes and hills. Filicales and the presence of other ferns (Dryopteris, Pteridum and Polypodium) are found throughout zone 1 and would mostly have been an understorey component of the nearby mixed deciduous woodlands (Brown et al., 2007). A small rise in arboreal and shrub taxa occurs between 178 and $174 \mathrm{~cm}$. This includes Pinus, Betula, Ulmus, Quercus, Fraxinus and Picea, as well as the shrub Corylus avellana type. Heathland, typified by Calluna vulgaris is present throughout zone 1, with the highest representation at $178 \mathrm{~cm}, 170-160 \mathrm{~cm}$ and $156-$ $152 \mathrm{~cm}$. There is also strong evidence to suggest the valley was considerably wet including low LOI, the presence of wet woodland and aquatic taxa. Wet woodland consisting of Alnus and Salix (Brown et al., 2007) was probably growing in the valley and/or on the floodplain. Cyperaceae, a major component of the $\mathrm{fen} / \mathrm{mire}$ vegetation is strongly represented in zone 1 . A proportion of Poaceae, along with the presence of Pedicularis and Sphagnum (peat moss), are probably also components of the fen/ mire. The parasitic plant Pedicularis is consistently present in this sub-zone, signifying damp/wet conditions either in wet grass/ scrub land or on heathland or bogs (Fitter et al., 1996; Stace, 2010). Standing water is represented by several aquatic taxa (although low percentages) including Callitriche which is frequently present - it can be found in a range of wetland habits from wet mud, brackish water, fresh water at varying depths, and in still, slow or fast-moving waters (Fitter et al., 1996; Stace, 2010). Typha sp. is also frequently present. Both T. latifolia and T.angustifolia are associated with swamps or freshwater margins (Fitter et al., 1996). The presence of aquatic algae in this subzone, notably HdV-731 type, Spirogyra and occasional Mougeotia support the pollen record. HdV-731 type displays an almost 


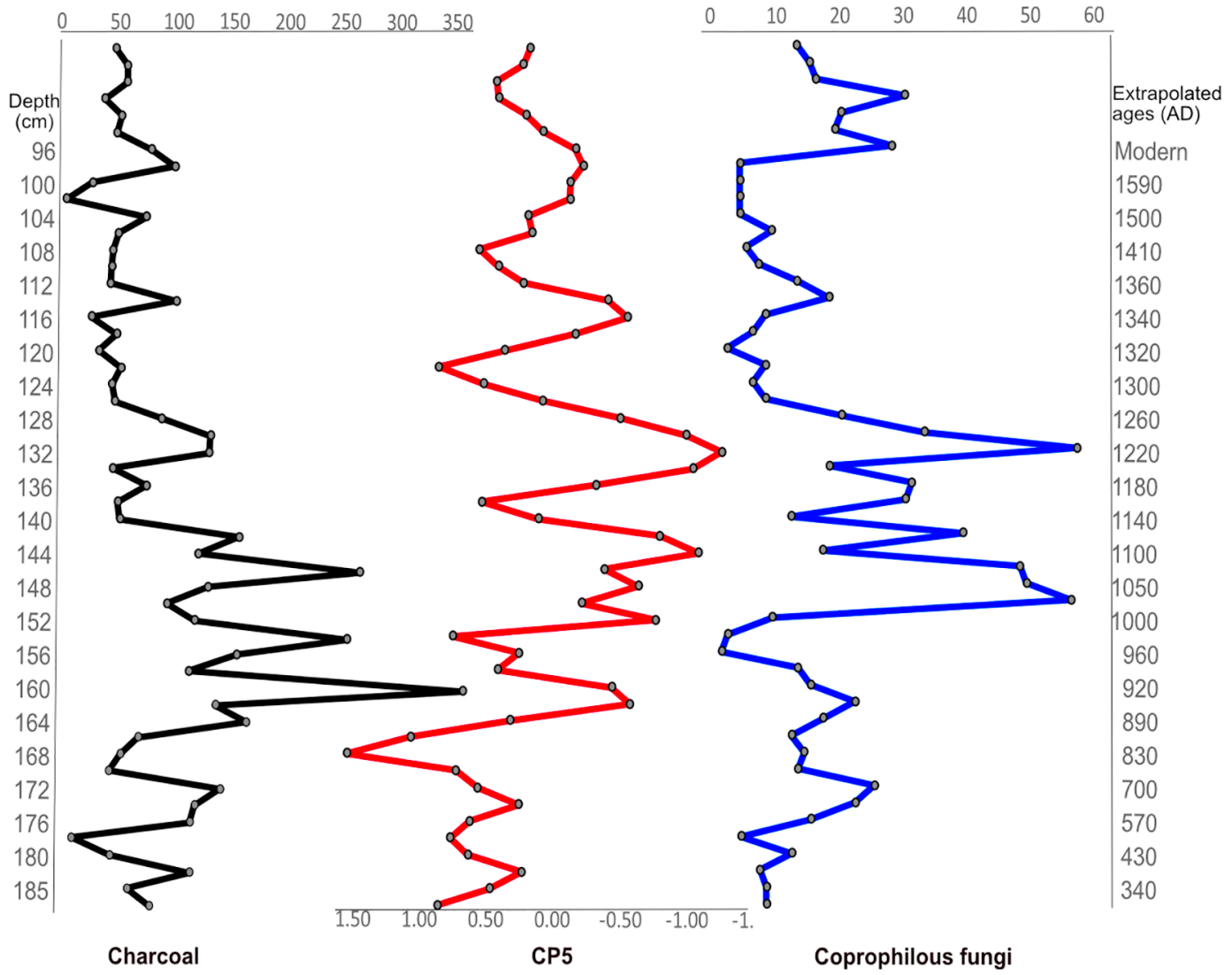

Figure 5. Comparison of component 5 (Cp5)-middle, which reflects the inverse relationship between $\mathrm{Zr}$ (negative loading associated with erosion) and $\mathrm{Mn}$ (moderate positive loading which may be associated with a rise in the water table and anoxic conditions), with microscopic charcoal-left, and coprophilous fungi (Sporormiella \& Sordaria types)-right from the Craw Stane mire sequence.

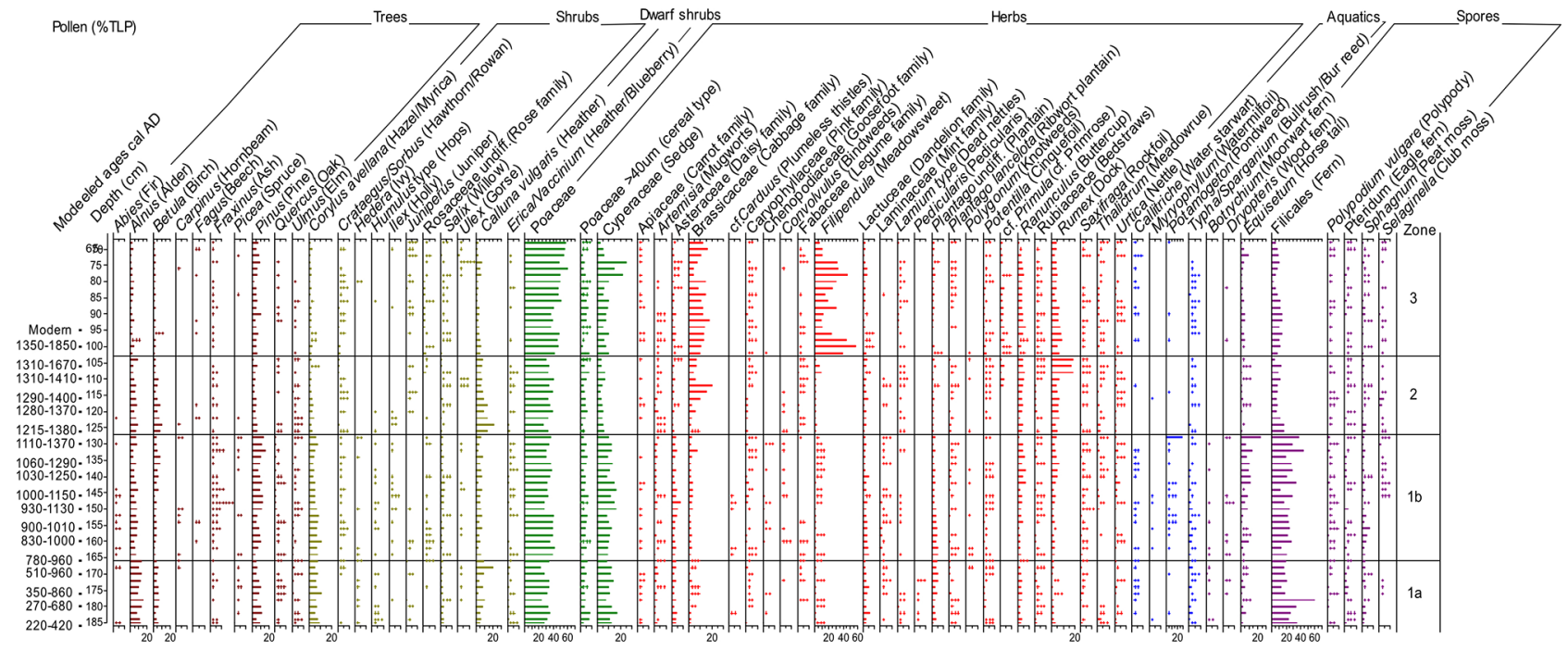

Figure 6. Pollen results; rare types: ++ .

continuous representation throughout zone 1. Bakker and Van Smeerdijk (1982) describe HdV-731 as preferring rather wet meso-eutrophic conditions in Sphagnums helophyte vegetation (see Supplemental Material 2 for images and morphology). This would fit quite well with the environmental conditions on the mire. Valsaria type (HdV-263) or a different species within the Dothideomycetes class is well represented in zone 1a, although the genus Valsaria seems to be rare in Scotland today with only an unconfirmed presence recorded in western Scotland (NBNatlas, 2021). In terms of ecology, Pseudovalsaria has been recorded on Alnus wood (Spooner, 1986) whilst Van Geel et al. (2003) describes Valsaria variospora (HdV-140) as often found under eutrophic wet conditions. Valsaria type in this record appears to show some association with the aquatic NPP group and was perhaps growing on rotting plant remains caused by the waterlogged conditions of the mire.

There is also considerable representation of open-ground vegetation, most often associated with human activity. Herbaceous taxa indicative of pasture and disturbance are well represented including Asteraceae, Lactuceae, Plantago undiff., Potentilla, Ranunculus and Plantago lanceolata (Brown et al., 2007). Poor preservation at times has meant that it was not always possible to 


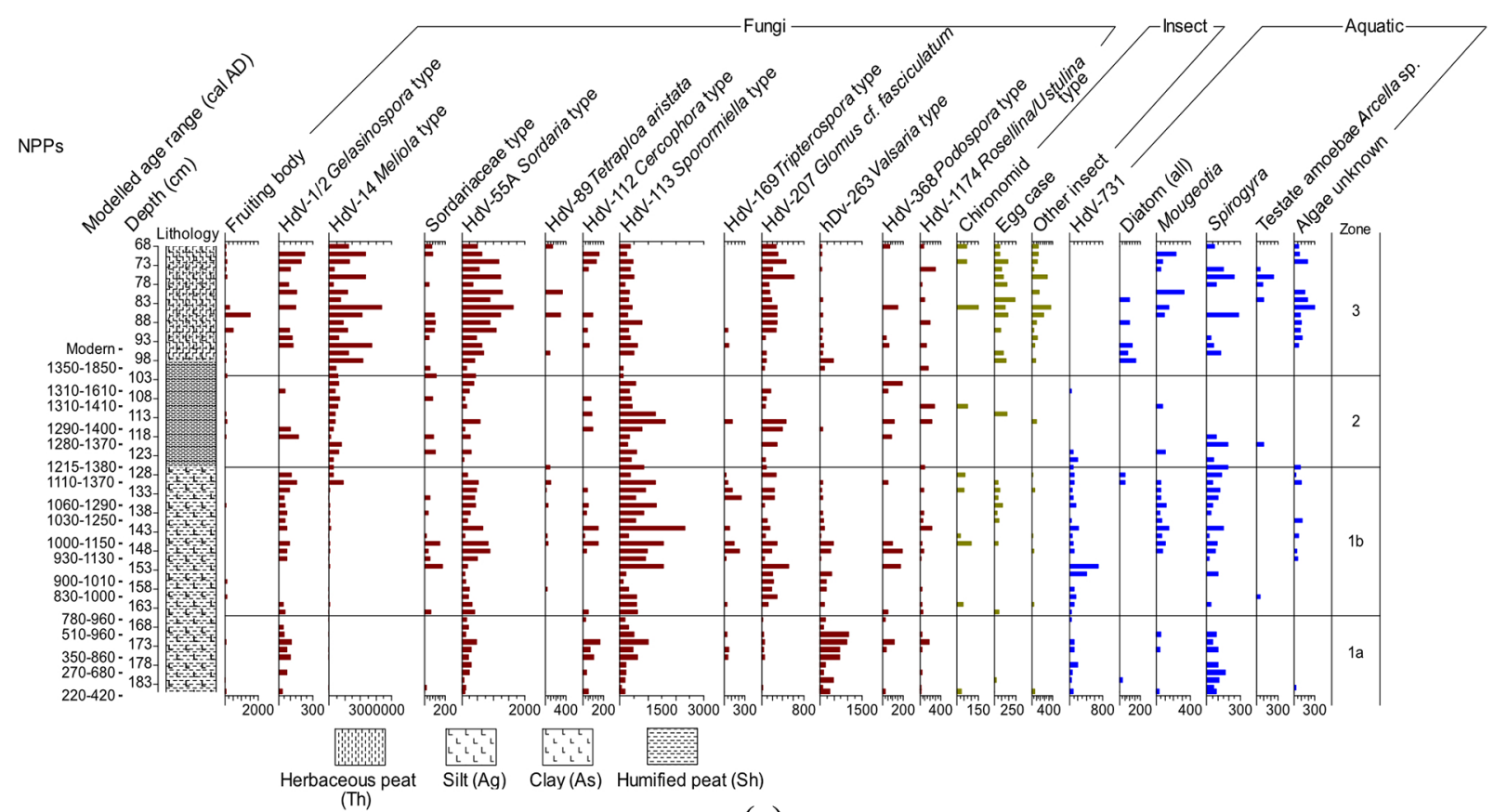

(a)

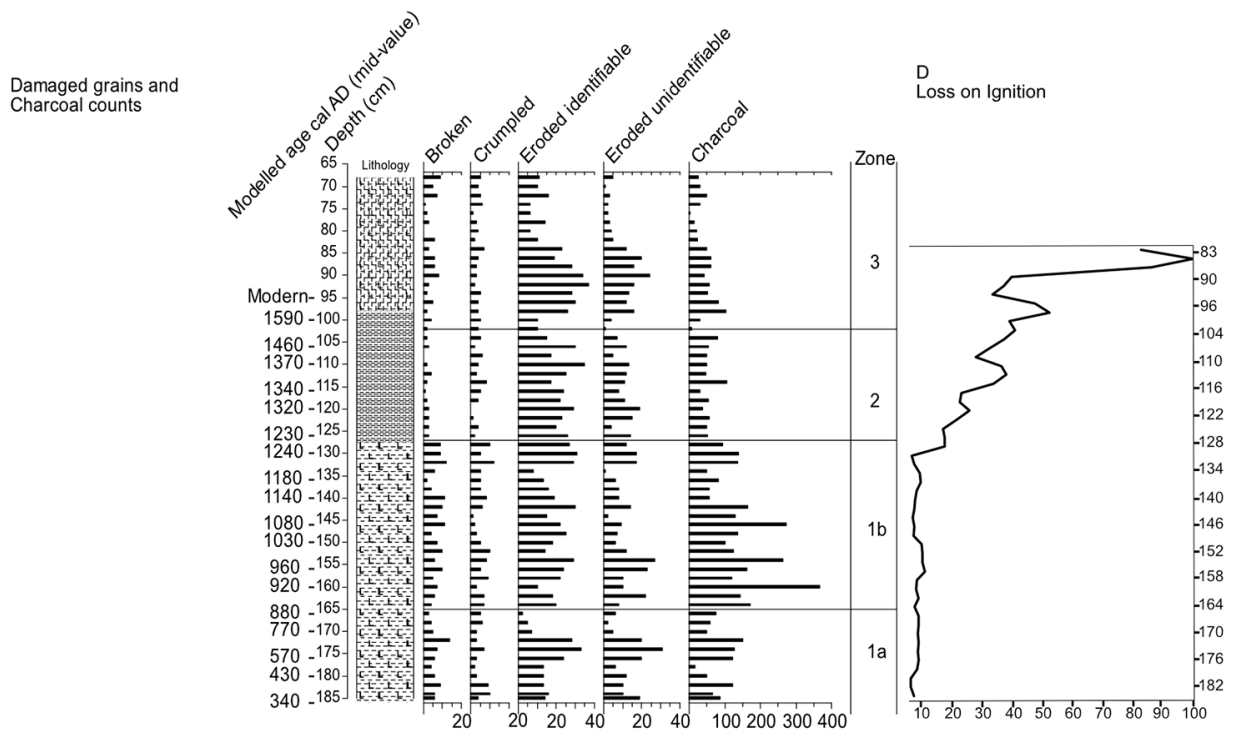

(b)

Figure 7. (a) NPP results; rare types. (b) Degraded grains, microscopic charcoal $>5 \mu \mathrm{m} \&$ C: Loss on Ignition (LOI).

distinguish Plantago lanceolata from other Plantago species. This may mean that the recorded representation of Plantago lanceolata is higher than actual representation. Coprophilous fungi often associated with herbivore dung include Podospora type, Tripterospora type, Cercophora type, Sporormiella type and possibly Sordaria type (Van Geel et al., 2003). Sporormiella, Sordaria type and Gelasinospora type are frequently present in this sub-zone. Previous studies suggest Gelasinospora type are carbonicolous and are either an indicator of fire or representative of drier conditions (Van Geel, 1976). In this record fluctuations in the concentrations of Gelasinospora, Sporormiella and Sordaria types have been influenced to some extent by terrigenous in-wash (see XRF results section 4.3 and Figure 4). Fluctuations in coprophilous fungi similarly show some association with damaged/ corroded pollen and peaks in charcoal, which further supports their arrival through minerogenic deposition. Other authors have identified a link between minerogenic deposition and fluctuations in coprophilous NPPs, particularly Sporormiella-type, although Mighall et al. (2012) argue that the presence of these NPPs is still a useful proxy for local grazing. The presence of high amounts of microcharcoal in this current investigation probably signifies that at least some of the minerogenic deposition has been initiated through woodland/scrub fires, either natural or anthropogenic.

Evidence of arable farming is strongly visible throughout the record as cereal type pollen is consistently present and generally greater than $2 \%$ (6.5 and $7.3 \%$ between 184 and $182 \mathrm{~cm})$. Although some of the grains could potentially belong to Glyceria fluitans, measurements of the annulus diameter and long diameter suggest the majority likely belong to Hordeum vulgare, whilst small amounts of Avena/Triticum may also have been present (Supplemental Material 1). During the Craw Stane enclosure period the results from the cereal measurements suggest that 9/95 of the grains are of Triticum/Avena size, 1/95 shows a Triticum/ Avena-Hordeum overlap, 10/95 show a potential Glyceria/Hordeum overlap whilst the remaining majority 75/95 most likely belong to Hordeum vulgare (see Supplemental Material 1). This supports the archaeobotanical findings since Hordeum vulgare macrofossil remains have been confirmed from just outside of the 
annexe enclosure at the Craw Stane by Ramsay (2019). Towards the end of the Craw Stane enclosure period a potential decline in arable farming is represented at $174-172 \mathrm{~cm}$ where cereal type representation falls to $3.6-3.2 \%$. The slight decline could be an artefact of sampling, but small increases in microscopic charcoal $>5 \mu \mathrm{m}$ were also recorded between 176 and $172 \mathrm{~cm}$.

Zone 1b (164-128 cm): AD 800-1200 (Grey-brown organic silty clay)

Trees more commonly found in south England and Wales, such as Carpinus, and southern England-southern Wales, such as Fagus (Stace, 2010) are present in this zone; however, both wet deciduous and evergreen woodland representation is low between 166 and $158 \mathrm{~cm}$, including Alnus and Betula. Arboreal taxa increase between 156 and $152 \mathrm{~cm}$ and this seems to coincide with an increase in heathland, herbaceous taxa, Typha/Sparganium type, damaged pollen grains (Figure 7b), microcharcoal and by a rise in principle component 5 (Figure 5). Increased fires in the locality (anthropogenic or natural) may have amplified erosion and the transportation of arboreal and regional pollen grains to the core location. Burning, erosion and increased wetness on the mire may also have facilitated the spread of wet grassland and herbaceous taxa such as Plantago. Glomus cf. fasciculatum type increases in zone $1 \mathrm{~b}$ and may further support increased erosion although Kołaczek et al. (2013) suggest that it can be naturally present on host plants growing on bogs. A similar pattern is represented in the coprophilous fungi and Gelasinospora records and with $\mathrm{Zr}$, represented by the negative values of Cp5 (Figure 5), which suggests increased minerogenic deposition. Other factors such as pastoral farming/grazing could potentially have impacted the record as well, since both the negative loadings of $\mathrm{Cp} 5$ and microscopic charcoal increase substantially before the main increases in coprophilous fungi (Figure 5). Reduced vegetation cover facilitated by fires may have allowed pastoral farming to expand in the locality, thus resulting in the later in-wash of these NPPs into the record. Other herbs, including Artemisia, Caryophyllaceae, Convolvulus, Plantago lancelota, Potentilla, Rumex, Ranunculus and Urtica are also prominent in the second half of zone $1 \mathrm{~b}$ (after $\sim \mathrm{AD} 1000)$ and thus might further reflect increased pastoral farming. In terms of other types of anthropogenic indicators cereal type pollen grains remain consistently present throughout zone $1 \mathrm{~b}$ suggesting people were still practising arable farming.

The presence/absence of aquatic algae Mougeotia and Spirogyra may be linked to changes in the water table or nutrient inwash. Spirogyra, particularly above $164 \mathrm{~cm}$ seems to increase with or shortly after Glomus cf. fasciculatum type and might reflect eutrophication caused by the erosional in-wash of nutrients, although there are no obvious changes in LOI. The presence of Myriophyllum and a more consistent presence of Potamogeton between 165 and $145 \mathrm{~cm}$ is consistent with still or slow-moving water at varying depths (Fitter et al., 1996). Potamogeton rises sharply at $128 \mathrm{~cm}$ and is potentially associated with minerogenic deposition since the rise occurs just after an age-reversal and dip in LOI.

Mire/fen conditions still persist with a slight increase in the mosses Sphagnum and Selaginella. A rise in Equisetum is represented above $150 \mathrm{~cm}$. Many Equisetum species are associated with damp ground (Stace, 2010). Other fen/mire taxa present include Cyperaceae.

Zone $2(130-100 \mathrm{~cm})$ : AD 1200-1560 (Dark brown, fibrous reed swamp peat)

Zone 2 represents an increase followed by a decrease in arboreal taxa. Betula and Alnus tree pollen initially increase, particularly between 126 and $118 \mathrm{~cm}$. These species may have been growing along the Water of Bogie or represent continued wet woodland. Birch, however, grows well on both wet and dry land. It is an early-pioneer species and would have successfully colonised open ground and forest-gaps. The later decline in arboreal taxa is predominantly associated with Pinus, whilst Abies and Picea disappear. Shrubs also fall including Corylus avellana type; Hedera and Ilex. Juniperus however, is consistently present whilst Crataegus/Sorbus increase. The woodland fern Polypodium vulgare remains present throughout most of zone 2, but Filicales (which could represent woodland or an open habitat) shows a prominent decline, and both Botrychium and Dryopteris disappear. Botrychium is mainly a species of damp upland grassland (Page, 1997. p.140). Its disappearance might be the result of a change in grazing or fire regime and might be linked with the rise of heathland taxa in this zone.

Despite the continued presence of wet woodland taxa there appears to be a general decline in wetness. The aquatics Callitriche and Potamogeton, Myriophyllum disappear apart from sporadic occurrences, along with all aquatic algae, diatoms and HdV-731 between 120 and $115 \mathrm{~cm}$. The decline in Spirogyra and Mougeotia is potentially associated with a reduction in eutrophication (nutrient in-wash) perhaps linked to peat accumulation, which is represented in the lithology and by increased LOI. Mire/fen communities principally Cyperaceae and Sphagnum moss also decline, as does Equisetum, associated with damp ground. However, Filipendula and the club moss Selaginella increase. Selaginella is pronounced between 118 and $116 \mathrm{~cm}$. The change in both mire/fen taxa and aquatics likely reflect the terrestrialisation of the core location. This is also reflected in the more sporadic representation of Glomus cf. fasciculatum type and Rosellina/Ustulina type. Broken pollen grains decrease suggesting a reduction in the mechanical breakage of pollen grains during transport (Cushing, 1967; Delcourt and Delcourt, 1980). Microscopic charcoal counts are also generally lower in the organic-rich deposits of zone 2 than in the silty-clay deposits of zone $1 \mathrm{~b}$, which suggests either a decline in fire or that peat accumulation reduced allochthonous deposition to the core location. An initial increase in the dry heathland taxon Calluna vulgaris, increase in Meliola type and presence of the bracken fern Pteridium potentially also reflect a reduction in woodland. Meliola type is found in relatively dry Calluna peat (Van Geel, 1976). It also shows a positive association with LOI (organic accumulation) particularly above $130 \mathrm{~cm}$.

Continued arable and pastoral land is represented by high amounts of Poaceae and cereal type pollen and by the continued presence of Apiaceae, Artemisia, Lactuceae and Plantago lanceolata. Other herbaceous taxa associated with disturbance or pasture (Brown et al., 2007) show a significant increase in the second half of zone 2 including Brassicaceae (above $116 \mathrm{~cm}$ ) and Rumex (above $110 \mathrm{~cm}$ ). Small increases in herbaceous pollen are also represented in the second half of zone 2 by Asteraceae, Potentilla and Ranunculus undiff. Primula type appears for the first time at $112 \mathrm{~cm}$ and is then consistently present. These changes coincide with a gradual decline in arboreal pollen including Quercus, Alnus and Betula, a continued decline in Pinus and Corylus, and a gradual decline in heathland taxon Calluna vulgaris and are likely associated with more intensive anthropogenic land use and clearance. In contrast most coprophilous fungi concentrations show a noticeable decline, but this is likely associated with a change in taphonomy (peat accumulation and a reduction in terrigenous inwash). Some evidence of pastoral farming is potentially represented in the coprophilous fungi record, however, by an increase in Sporormiella type between 114 and $112 \mathrm{~cm}$, by a gradual increase in Sordaria type in the second half of zone 2 and by sporadic occurrences of Podospora and Cercophora types.

Zone 3 (100-68 cm): 1560 - Post 1950 (Dark brown, very loose fibrous reed swamp peat)

This zone is represented by a significant decline in Betula and Alnus, although Pinus increases. Heathland remains present and grassland is still prevalent with Poaceae pollen values well represented with slight increases. Brassicaceae, Rumex and Ranunculus pollen increase whilst other herbaceous taxa associated with 
disturbance or pasture are present including Apiaceae, Asteraceae, Caryophyllaceae, Lactuceae, Plantago lanceolata and Pontentilla (Brown et al., 2007). Cereal-type pollen fluctuate. Coprophilous fungi increase most notably Sordaria type and Sporormiella type, with Cercophora type, Podospora type and Tripterospora type sporadically present. These are potentially associated with a rise in terrigenous in-wash and/or increased pastoral farming. Broken pollen grains increase slightly and coincide with small peaks in charcoal, Cp5 and the negative loadings of $\mathrm{Cp} 1$ (Figures 4, 5 and 7b) suggesting a slight increase in erosional in-wash. Erosion is also indicated by the presence of Glomus $\mathrm{cf}$. fasciculatum type and potentially by the reappearance of the eutrophication algae Spirogyra and Mougeotia.

Cyperaceae, Filipendula, Equisetum and Sphagnum spores increase in zone 3 suggesting an increase in mire/fen plant communities. This is further supported by the appearance of testate amoebae Arcella sp., and the reappearance of Valsaria type, diatoms, eutrophication algae and the aquatic pollen of Callitriche which suggests the presence of a wetter substrates/open water. Other algae and aquatic pollen, however, disappear or only show sporadic representation including HdV-731, Potamogeton and Myriophyllum, which might suggest a shallower water body compared to zones $1 \mathrm{a}$ and $1 \mathrm{~b}$.

\section{Discussion}

\section{AD 220 to $A D 560$ - Natural environment}

The near base (at $181-182 \mathrm{~cm}$ ) of the core produced a calibrated age of AD 260-415 (mid-value $\sim$ AD 340) which overlaps and probably precedes the start date for the enclosure complex at the Craw Stane: cal AD 330-390 (95\% probability) and Cairn More: cal AD 370-540 (95\% probability) (Noble et al., 2019a; unpublished data). While the coring site at the time appears to have been suitable for wet woodland and marsh/fen species, low LOI (Figure 7c) and high negative scores representing mineral input in $\mathrm{Cp} 1$ of the XRF results (Figure 4) suggest the valley was part of a river floodplain; it is quite possible the Water of Bogie was much closer to the core site than today. Variations in $\mathrm{Cp} 1$ of the XRF record (Figure 4) suggest fluctuations in the intensity of terrigenous deposition and organic accumulation, where increases in organic accumulation appear to be closely coupled with high positive loadings for metals $(\mathrm{Pb}, \mathrm{Zn}, \mathrm{Cu}, \mathrm{As}, \mathrm{Ni}, \mathrm{Fe})$ and high negative loadings for ( $\mathrm{Sr}$ and $\mathrm{K}$ ) mineral accumulation and vice versa. The presence of the aquatics HdV-731, Mougeotia and Spirogyra suggests eutrophic-stagnant conditions (Bakker and Van Smeerdijk, 1982; Van Geel, 2006) and may be associated with high positive loadings for $U$ (Table 3 and Figure 4) recorded in the basal Cp4 XRF record, until AD c. 360. Shotyk (1988) associates $\mathrm{U}$ enrichment with the anaerobic environments of bogs. A change to predominantly negative or close to zero values of $\mathrm{U}$ after AD c. 360 may signify a decline in anaerobic conditions on the mire surface.

\section{AD 220-AD 560 - The fortified settlement period}

Away from the wetland, the environment appears to have been heavily dominated by grassland. This could represent natural wet meadow and/or drier grassland on the valley sides and around the nearby-enclosed settlements at the Craw Stane and Cairn More for pasture. Fungi commonly associated with herbivores (Van Geel, 1978) are prominent in zone 1a and throughout the record, notably Sporormiella type and Sordaria type, but also Cercophora type, Podospora type and Tripterospora type. Consistent representation of Lactuceae and Asteraceae as well as Plantago undiff./lanceolata, Ranunculus and some Rumex (Brown et al., 2007) support the presence of a pastoral economy. Fluctuations in coprophilous fungi, particularly Sporormiella type, however, show a strong association with the negative loadings of $\mathrm{Cp} 5$ (Figures 4 and 5), which suggest their deposition through increased runoff and terrigenous in-wash. The association with mineral inwash means that although the presence of coprophilous fungi together with certain herbaceous taxa do give an indication of pastoral farming, fluctuating representation here cannot be used solely to infer changing agricultural patterns or densities of landuse. Their low representation or absence was possibly influenced by low energy transport to the deposition site (through reduced erosion/stream or fluvial energy), and high representation due to high-energy transport (increased erosion/stream/fluvial discharge). A link between damaged pollen and erosion/fluvial transport is also evident by a higher representation of broken and crumpled pollen grains in zones $1 \mathrm{a}$ and $1 \mathrm{~b}$ compared to zone 2 when the core comprised peat (Cushing, 1967; Delcourt and Delcourt, 1980).

Arable farming and the deposition of cereal pollen to the coring site does not appear to have been influenced by in-wash. Cereal type pollen is represented throughout this zone and typically values greater than $2 \%$ are reached. The highest representation of cereal type pollen in this zone is recorded between 184 and $182 \mathrm{~cm}(6.5$ and $7.3 \%)$. The high values here could potentially be associated with the beginning and floruit of the Craw Stane enclosure period. Cereals are low pollen producers (Tweddle et al., 2005); therefore, the cereal type pollen representation in this record may signify arable farming in the immediate vicinity of the core location - that is, close to the Craw Stane complex (Hall, 1989, 2000). Despite the potential overlap between wild grass species and cereals, biometric data on a selected number of cereal types suggest most grains identified probably belong to Hordeum vulgare $(\sim 79 \%)$, whilst a smaller percentage $(\sim 10 \%)$ might belong to either Avena or Triticum. The barley type pollen grains are further supported by small quantities (28 grains) of macro-fossil remains (Hordeum vulgare and indet. types) from the adjacent Craw Stane enclosure (Ramsay, 2019). The small quantities of macrofossil remains came from deposits just outside of the annexe enclosure from a fill which may have been the floor layers of a sunken enclosure or other structure suggesting that the processing of cereals was conducted outside of the main enclosure complex (Noble et al., 2019a; Ramsay, 2019). The evidence for grassland, grazing and arable farming shows that the Picitsh elite centre was located within and supported by a vibrant agricultural base economy.

In addition to arable-pastoral farming, wild plant resources would probably have been an important dimension of the economy and environment of the site. This is highlighted in the macrofossil record by traces of hazelnut and fucoid seaweed from the Craw Stane enclosures (Ramsay, 2019), which have been directly dated to the early medieval period (Noble et al., 2019a). The fucoid seaweed is unusual since the Craw Stane complex is $50 \mathrm{~km}$ inland. Its purpose at the site is unknown but it could have been used as a fertiliser, although other uses (e.g. in metalworking, as a food, fodder, medicinal, religious or other resource) are also possible (Kenicer et al., 2000). A variety of woodland resources would have been more widely available for the Pictish inhabitants living at the Craw Stane complex and nearby Cairn More compared to today. The woodland/semi open woodland may have been composed of both deciduous and coniferous trees and shrubs, particularly pine, but also some alder, willow, hazel, birch, oak, ash and elm. At Cairn More hazel has been identified from burnt deposits on top of rampart 3 and alder from the primary fill of a foundation cut of rampart 2 (Noble et al., 2013). However, neither the Cairn More or Craw Stane archaeobotanical records have identified pine (Noble et al., 2013; Ramsay, 2019), thus its representation in the pollen record may be a regional signal. Most of the other woodland taxa identified in the pollen record were perhaps growing on the slopes around the Water of Bogie and on 
the adjacent hills, in well drained soils away from the valley wetlands, except alder and willow which are components of wet or moist woodland (Brown et al., 2007). The archaeological records also provide some evidence regarding the variety of woodland resources used by the Craw Stane and Cairn More communities. Birch appears to have been widely utilised at the Craw Stane complex and was found to be the dominant plant taxon in charcoal assemblages from the ditches, palisade and interior of the enclosure; to a lesser extent hazel, oak and willow have also been identified (Ramsay, 2019). Ramsay (2019) suggests this assemblage is more akin to hearth or midden material than burnt structural remains since birch is only rarely used as a structural timber. In terms of structural indicators there is tentative evidence for burnt willow wattle and an oak post in the interior of the enclosure, whilst at a structure near to the Craw Stane the charred remains of oak and alder planks were identified (Ramsay, 2019). At Cairn More, alder, birch, hazel and willow were utilised and one postpipe had abundant oak suggestive of the use of oak as a structural material. The use of oak at the Craw Stane complex and at Cairn More is interesting since Quercus pollen only represents $0-3 \%$ of the TLP which suggests at least some of the oak timber may from both sites have been sourced from further afield.

Minerals were perhaps some of the most valuable resources available to the Craw Stane inhabitants in terms of trade, elevating status and local usage. This is perhaps evidenced to some extent by the XRF mire record of Cp3 from AD 360, which is predominantly representative of the metal's $\mathrm{Cr}$ as well as, in part, $\mathrm{Ni}, \mathrm{Fe}$ and Y (Figure 4). Some caution is needed with this interpretation however, as the signals may equally come from natural catchment sources. The evidence probably leans more towards catchment rather than metalworking since major elements associated with metal working such as $\mathrm{Pb}$ and $\mathrm{Cu}$ are absent from $\mathrm{Cp} 3$, and only trace amounts of $\mathrm{Ni}$ and $\mathrm{Fe}$ are present. The strongest evidence of mineral exploitation is supported by the archaeological XRF record, particularly from the geochemical analysis conducted on selected crucibles and moulds from the Craw Stane complex assemblage (Young and Hamilton, 2017). This includes varying amounts of lead $(\mathrm{Pb})$, copper $(\mathrm{Cu})$, zinc $(\mathrm{Zn})$, iron $(\mathrm{Fe})$, nickel $(\mathrm{Ni})$, manganese $(\mathrm{Mn})$, silver $(\mathrm{Ag})$, gold $(\mathrm{Au})$, tin $(\mathrm{Sn})$, cadmium $(\mathrm{Cd})$ and chromium $(\mathrm{Cr})$. Dominant elements include $\mathrm{Pb}, \mathrm{Cu}$ and $\mathrm{Fe}$. Natural contaminants potentially include chromium and nickel as only trace amounts of these elements were detected on most of the moulds and crucibles; as with the mire XRF results these elements may have originated from rocks/sediments within the catchment. The iron content on the crucibles and moulds may also represent natural contamination given that iron would likely have been hammered from a bloom and not cast in a mould.

\section{AD 560-800 - Settlement abandonment}

By cal AD 560 the Craw Stane enclosure appears to have been abandoned (Noble et al., 2013, 2019a), but this does not necessarily reflect abandonment of land use in the wider locality and certainly dates from Cairn More suggest occupation into the seventh century AD and tentatively Tap o' Noth may have stayed in occupation into at least the late sixth $\mathrm{AD}$ century based on preliminary dating. The metal signal in Cp3 (Figure 4), apart from a small decline $\sim \mathrm{AD} 500$, continues to increase until $\sim \mathrm{AD} 700$ before decreasing. Even though this is probably a catchment rather than metal working signal, fluctuations in $\mathrm{Cp} 3$ may have some association with anthropogenic burning and allochthonous deposition. There is no evidence in the LOI record (Figure 7c) or Cp1 (Figure 4) to suggest fluctuations in the amount of erosion during this time, but a rise and fall in allochthonous input is potentially represented by the positive and negative loadings of $\mathrm{Cp} 5$ (Figures 4 and 5) associated with $\mathrm{Zr}$ and redox conditions. Minor increases in microcharcoal are recorded from the mid-sixth century AD (Figures 5 and $7 \mathrm{~b}$ ) until the seventh century AD. It is clear from the geochemical record ( $\mathrm{Cp}$ 5, Figure 5), which shows an almost simultaneous albeit slightly delayed rise in zirconium and microcharcoal, that fire within the catchment area could have caused some erosion. Although natural fires should not be ruled out, at least some of the catchment fires and subsequent erosion might be attributed to activity - perhaps continuing occupation at Cairn More and Tap o' Noth, but also potentially destructive events at the Craw Stane enclosure, since significant quantities of burnt material were recorded from the final phases of the site, including burnt turf and large charred timbers (Noble et al., 2013, 2019a). Some of the catchment fires and subsequent erosion (Figure 5) might also represent continued land-use after the Craw Stane enclosure period in the sixth century $\mathrm{AD}$, via the burning of vegetation until $\sim \mathrm{AD} 700$. As well as continued occupation at Cairn More, only $1.3 \mathrm{~km}$ south of the core location. Continued activity at least at one of the square enclosures at the Pictish cemetery during the seventh century AD reflects on-going occupation and exploitation of the landscape (Mitchell and Noble, 2017; Noble et al., 2019b). A pronounced decline in the positive scores in $\mathrm{Cp} 3$ and microcharcoal after $\sim \mathrm{AD} 700$, might reflect the later abandonment at Cairn More, and possibly abandonment of Tap o' Noth.

With the demise of the Craw Stane complex in the sixth century $\mathrm{AD}$ there is potentially some indication that the economy may have briefly regressed in association with this particular site. For example, a rise in arboreal and shrub taxa between 178 and $174 \mathrm{~cm}$, and a brief decline in cereal type pollen might reflect a lowering of population during the sixth century AD. However, the cereal type pollen representation also indicates continuity in arable farming, right up until more recent times. The presence of coprophilous fungi and herbaceous pollen such as Asteraceae, Lactuceae, Potentilla, Rumex spp., Ranunculus and Plantago lanceolata may also indicate continued pasture/grazing. This suggests that while Rhynie is located towards the edges of the fertile farming land of central Aberdeenshire, it has been more than capable of supporting a local population as reflected by the number of archaeological sites spanning the Neolithic/Bronze Age to the early Medieval period (Figure 2) from prehistory to modern times. Moreover, despite the abandonment of one of the elite complexes in the valley in the sixth century AD this continued to be a populated and utilised landscape.

Noble et al. (2013, 2019a) suggest the abandonment of localised power centres coincides with the impact of Christianity from the late sixth century $\mathrm{AD}$ onwards and highlight the effects that the rise of the documented over-kingship of Fortriu in northern Pictland may have had on centres such as Rhynie (Noble et al., 2013; Woolf, 2006). Fraser (2009: 214) describes the emergence of the kingdom of Fortriu as marked by aggressive military expansion in a variety of directions but dates the rise of Fortriu to the late seventh century $\mathrm{AD}$, which is too late to explain the abandonment of the Craw Stane complex. The connection of changes in secular power centres with Christianity is equally not clear and may have occurred later. The Craw Stane enclosure could have been abandoned for several reasons - religious change, climate change, disease or even political competition are all possibilities. A climatic cooling has been recorded between AD 536 and 545 and there is some historical documentation of crop failures in Ireland, Scandinavia, Mesopotamia and China (Gibbons, 2018). The Justinian plague also had a drastic impact on the Byzantine empire in AD 541-542, potentially wiping out $15 \%$ of the World's population (Benovitz, 2014; Caspermeyer, 2016; Gibbons, 2018). There is no historical evidence that the plague arrived in Scotland but there is some evidence of its arrival in England (Keller et al., 2019) whilst the residents of the Craw Stane complex were trading (directly or indirectly) with Byzantine merchants (Noble 
et al., 2013, 2019a). An alternative theory is that political competition may have witnessed the Craw Stane complex being replaced in importance by somewhere else in the locality such as Cairn More or the larger and more developed fort of Mither Tap, Bennachie (Noble et al., 2013); however, more archaeological investigation of enclosure sites is needed to understand these changes better. What is notable from the palaeoecological record is that, while a brief spell of aggression, change in religion or outbreak of disease could have seen a reduction in agricultural production, there is no evidence of abandonment within the Rhynie catchment (since there is continued cereal pollen, coprophilous fungi and herbaceous pollen associated with disturbance or pasture). It could be that the elite focus in this landscape moved to an as yet unattested location or that the agricultural resources of this landscape were diverted to provisioning an elite centre elsewhere through food renders. Continued utilisation of the fertile agricultural land by a remaining community is equally possible. Whatever the case, the agricultural productivity of this landscape was continued.

\section{$A D$ 800- 1200 - Fires and erosion}

There are no directly dated archaeological sites of this period in the Rhynie valley. By the late 12 th or early 13 th centuries Rhynie was part of the Lordship of Strathbogie. However, the Strathbogie name is cited earlier. It appears in one textual group of the king lists of the Scots, in additions datable to about 1124, that mention the killing of King Lulach mac Gilla Comgáin (1057-1058), the nephew and successor of King Mac Bethad mac Finnlaích (10401057), in Strathbogie at Essie, $3 \mathrm{~km}$ west of Rhynie (Anderson, 2011; Broun, 1999), suggesting that the Rhynie valley retained some importance in medieval social-political geography. However, the elite focus in the 12 th to early 13 th century in the region shifted $12 \mathrm{~km}$ northwards to Huntly with the construction of a motte and bailey that formed the lordship centre of Strathbogie (Simpson, 1922).

From AD 800 to AD 1200 increased human activity is potentially represented in the pollen record (zone 1b, Figure 6) by a decline in heathland, birch and alder, and a small expansion in grassland. The changes recorded in the pollen record appear to coincide with a period of increased fire, enhanced runoff and soil erosion, identified by distinct see-saw fluctuations in the microcharcoal record and in the negative-positive loadings of $\mathrm{Cp} 5$ (representative of mineral input - $\mathrm{Zr}$ and redox conditions - $\mathrm{Mn}$ in the valley) (Figure 5). The most pronounced peaks in $\mathrm{Cp} 5$ occur slightly later than that of charcoal (Figure 5). These results might signify a delayed response to fire with significant erosion taking place after a period of prolonged fire. There are no distinct changes in LOI during this period, although minor fluctuations can be seen between 168 and $158 \mathrm{~cm}$. Any changes would probably have been masked by the beginning of very low peat accumulation at the site. Glomus cf. fasciculatum type does increase and is often associated with erosion although it can also occur naturally on host plants (Kołaczek et al., 2013). While natural fires should not necessarily be ruled out and may have been a contributing factor, the cyclic nature of the charcoal peaks and $\mathrm{Cp} 5$ together with the decline in heather, birch and alder could potentially represent fire management of the surrounding heathland and woodland (e.g. Gimmingham, 1972; Hobbs et al., 1984).

Cereal pollen percentages remain relatively consistent, suggesting continuity in arable farming throughout this period although percentages dip at $160 \mathrm{~cm}(\sim \mathrm{AD} 830-1000)$ and between 150 and $148 \mathrm{~cm}$ ( AD 930-1130). This contrasts with coprophilous fungi types and Gelasinospora type, which appear to have been amplified by terrigenous in-wash. Their appearance also coincides with a rise in eutrophic algae Spirogyra and Mougeotia. The increase in coprophilous fungi also coincide with a rise in herbaceous pollen taxa (e.g. Artemisia, Lactuceae, Caryophyllaceae, Chenopodiaceae, Convolvulus, Potentilla, Rumex and Ranunculus) often associated with disturbance and pasture (Brown et al., 2007). Even though terrigenous inwash is likely a contributing factor, a change in pastoralism has probably also impacted these results.

\section{AD 1200-1560 - Intensification of anthropogenic land use}

From $\mathrm{AD} \sim 1300$, permanent woodland clearance is suggested by a gradual decline in tree and shrub pollen, although alder, birch and heather increase initially. At the same time Brassicaceae pollen grains show a prominent increase with highest representation reaching $19 \%$. Such a prominent rise might be attributed to the introduction of a new food crop (e.g. turnips, rape, kale and cabbage all belong to the Brassicaceae family). Historical records suggest that turnips were an important food crop locally during the 1700 s- 1800 s since they are well documented in the parishes of Rhynie and Kearn (Lewis, 1846; NSA, 1845; OSA, 1794, 1797). Both turnips and cabbage (also a Brassica) however, have been grown as a vegetable in Britain since at least Roman times (Cool, 2006; Hall and Kenward, 1990; Hartley, 1954; Van der Veen et al., 2008) and potentially even earlier. At the Iron Age broch at Bru, Gurness, Orkney, five Brassica rapa (turnip) seeds were identified from floor/midden deposits dating between 800 and 460 BC (Dickson, 1987). Brassica sp. was also identified in Iron Age deposits from Surrey (Murphy, 1979). According to Berry (2018) the break-up of feudal systems in England after the Black death from 1348 encouraged more innovative farming and the spread of root crops such as carrots and turnips although there is no literary evidence for the adoption of turnip in Scotland during this time. In fact, turnips may not have become a significant field crop in Britain until the end of the $18^{\text {th }}$ century, and this was largely facilitated by the agricultural revolution (e.g. Bradshaw et al., 2002; Riddet, 1925). Thus, the cause of the rise in Brassicaceae pollen grains remains uncertain.

Besides potential Brassica farming for cabbage or root crops, other forms of agricultural activity at Rhynie still persisted between AD 1200 and 1500 with regular occurrence of cereal type pollen and herbaceous pollen associated with both arable and pastoral agriculture (e.g. Ranunculus type, Plantago lanceolata, Lactuceae). Coprophilous fungi are also still consistently recorded. There is a significant decline in these NPPs, but this is probably associated with a change in taphonomy caused by terrestrialisation of the mire/fen rather than a decline in pastoralism. Cyperaceae and Sphagnum decline and appear to have been succeeded by other marsh/bog taxa such as Filipendula and Selaginella (Figure 6). The lithology (Table 2), LOI (Figure 7c) and $\mathrm{XRF}$ records of $\mathrm{Cp} 1, \mathrm{Cp} 3$ and $\mathrm{Cp} 5$ (Figures 4 and 5) show a significant period of peat accumulation and decrease in minerogenic deposition, which would have impacted the arrival of coprophilous fungi to the core site.

In terms of historical evidence, a castle at Druminnor, just to the east of Rhynie, a seat of the Forbes family, may have been established in the 13th century (Shepherd, 2018) and a church at Rhynie (Ryny) is recorded from episcopal records from 1266 (Ross, 2003), while St. Mary's Kirk (Figure 2) south of Rhynie in the parish of Auchindoir also appears around the 13th century (Simpson, 1930), indicating that a substantial number of people would have been living in the area and utilising the land. There is no evidence for a discontinuation or downturn of cultivation and/ or grazing despite this time being a period well known for famine and plague (e.g. the bubonic plagues of AD 1350 and 1362-1363 which wiped out a third of the global human population) (Bower and Watt, 1990; Dennison et al., 2002; Skene, 1872, p. 359). Minerogenic inwash and microscopic charcoal counts do decline 
at the valley mire substantially after $\mathrm{AD} \sim 1300$ but this is again probably linked to terrestrialisation since there are no significant changes in the rest of the palaeoecological record.

\section{$A D$ I560 - Post 1950}

By AD 1600 the Rhynie valley and surrounding environment would have increased in population; it already consisted of six land units: Smyithistoune, Old and New Noithe, Scordarge, Ardloyne, Myttes and Rynie (Ross, 2003), and each of these units presumably had their own settlements which would have likely had some impact on the environmental record. Indeed from AD $\sim 1560$ there is a general reduction in deciduous tree taxa, continued evidence for cereal cultivation and land maintained for pasture, supported by the presence of cereal pollen and a suite of herbaceous taxa with cultural affinities (e.g. Brassicaceae, Plantago lanceolata, Lactuceae and Rumex) and coprophilous fungi (e.g. Sporormiella-type and Sordaria-type).

One of the most notable changes in the pollen record during this period, however, is a sudden increase in Filipendula pollen. Filipendula was probably part of the marsh/fen type vegetation community along with Cyperaceae and Sphagnum growing on the floodplain, although its increase coincides with an increase in the aquatic pollen taxon Callitriche and Typha/Sparganium suggesting a substantial rise in wetness, which may be associated with erosional or fluvial inwash. A rise in terrigenous sediment above $100 \mathrm{~cm}$ is demonstrated by increased negative scores in $\mathrm{Cp} 5$ and $\mathrm{Cp} 1$ and a drop in LOI at $90 \mathrm{~cm}$ (Figures 4 and 7c). Two small peaks of positive scores in $\mathrm{Cp} 2$ also suggest slight changes in mineralogy. Erosion is unlikely to have been responsible for increased negative scores of $\mathrm{Ca}$ and $\mathrm{S}$ in $\mathrm{Cp} 2$ (Figure 4) since the geology of the area is predominantly felsic-acidic, so the $\mathrm{Ca}$ might reflect liming of adjacent fields for agricultural purposes. $\mathrm{Cp} 2$ reaches its maximum negative values of the entire record above c. AD 1560.

In addition to increased wetness and mineral content, sediments above c. AD $1560(98 \mathrm{~cm})$ appear to be modern. The radiocarbon date at $110-111 \mathrm{~cm}$ is calibrated to between AD 1300 and 1400 , whilst $89-90 \mathrm{~cm}$ is modern ( 1950 onwards). This suggests a possible hiatus of $\sim 500-600$ years. In the late 1700 s the construction of the Bareflat (Barflat) cornmill and creation of a mill lead, sluice and weir system are probably predominantly responsible for the increase in minerogenic sediment and wetness and perhaps also for the hiatus. It is quite possible that the former water course represented in Figure 1b is also linked to the creation of the sluice and weir system. The mill is no longer present but would have been located close to the core location and is clearly marked on an 1866 First Edition Ordnance Survey map (National Library of Scotland, 2019). Its first mention appears on the farm horse tax rolls of 1797; Robert Shand, Mill of Bareflat in Kearn Parish (Scotlands Places, 2019).

\section{Conclusion}

The purpose of this investigation has been to provide new insights into societal change during the first Millennium $\mathrm{AD}$, with particular focus on unraveling the economy and environment that underpinned the rise to prominence of the early Pictish centres at Rhynie in NE Scotland. This has been achieved through detailed environmental analysis (pollen, NPP, ${ }^{14} \mathrm{C}$ and XRF analysis) compared with historical and archaeological records. The base of the core produced a calibrated age of AD $260-415$ and coincides with the earliest date ranges from the nearby enclosure at the Craw Stane. The early Medieval communities living at the Craw Stane, Cairn More and Tap o' Noth would have made use of the surrounding woodland resources, whilst archaeological evidence of metal working, and arable farming (predominantly barley cultivation, but perhaps also small amounts of wheat or oats) and pastoral farming is also evident at the Craw Stane. The clear evidence for mixed agriculture in the pollen sequence and from the site itself suggests that the site was not solely one of ritual, but a site set amongst and presumably supported by an agricultural economic base. The abandonment of the Craw Stane enclosure in the sixth century $\mathrm{AD}$ coincides with increased erosion and burning (increases in the negative loadings for $\mathrm{Zr}$ in $\mathrm{Cp} 5$ and rise in microcharcoal); at the same time a recovery in tree taxa, a very brief decline in cereal pollen and perhaps also by a small decline in the positive scores for metals (Cp3) suggest a potential short-lived period of economic regression. More archaeological research is, however, needed to completely understand why the Craw Stane and later Tap o' Noth and Cairn More enclosures were abandoned - religious change, disease or even political competition are all possibilities. While any one of these possibilities could have resulted in a reduction in agricultural production, there is no evidence to suggest the surrounding locality was abandoned. Cereal type pollen percentages recover and are present throughout the record which suggests people continued to utilise the landscape even after cessation of activity at the Craw Stane in the sixth century AD. It may be that the elite focus in this landscape moved elsewhere in the valley, perhaps to Tap o' Noth and the ringfort at Cairn More and perhaps elsewhere in Aberdeenshire such as the major hillfort at Mither Tap, Bennachie. Between AD 800 and 1200 , despite no archaeological sites having yet been identified that span this period, continued and perhaps more pronounced human activity is recorded in the form of fire and erosion. While natural fires should not necessarily be ruled out, the see-saw nature in fire and erosion events, later rise in coprophilous fungi with herbaceous pollen associated with disturbance and pasture, and a contemporaneous decline in heather and deciduous woodland might indicate growing heath and woodland management through deliberate burning. After AD 1200, fires, erosion and the metal signal (Cp3) decline substantially. A change in farming practices is potentially represented from the AD 1300s onwards with the introduction of Brassica, perhaps for cabbage or root crop cultivation, though this is not certain given the lack of literary evidence for this crop in Britain at this time. Historical records document several episodes of famine, disease and plague in Scotland between the 13 th and 18th centuries, but it is unclear to what extent these episodes would have impacted the communities living in the parishes around Rhynie. It is quite tempting to link the palaeoecological changes to these events, but cereal type pollen and other herbs do not decline during this period; the decline in fire, erosion and metals may instead reflect taphonomic changes caused by terrestrialisation of the valley mire. The accumulation of peat may have prevented charcoal, some coprophilous fungi, and some geochemical signals from reaching the mire. In more modern times a return to wetness is represented in the palaeoecological record and is probably associated with the construction of a corn mill, sluice and weir system in the late 1700 s.

To conclude, these results have not only provided a rare snapshot of the Late Roman to Medieval environment of Northeast Scotland but have also provided a detailed examination of settlement and land use during the rise to prominence and later abandonment of the early medieval enclosures of the upper Strathbogie valley showing that the elites in these landscapes lived in, and were supported by, a rich agricultural landscape. Despite the destruction and abandonment of these enclosures through time, people continued to utilise the surrounding landscape and available resources right through until modern times.

\section{Acknowledgements}

Special acknowledgements go to Audrey Innes for her laboratory support, to Edouard Masson-Maclean who helped with the extraction of the core and who got slightly wetter than intended, and to the Leverhulme Trust who have funded this project: Grant number RG13876-10. 


\section{Funding}

The author(s) disclosed receipt of the following financial support for the research, authorship, and/or publication of this article: Funding was provided by the Leverhulme Trust (Grant number RG13876-10).

\section{ORCID iDs}

Samantha E Jones (iD) https://orcid.org/0000-0002-0799-4840

Antonio Martínez Cortizas (iD https://orcid.org/0000-0003-04305760

\section{Supplemental material}

Supplemental material for this article is available online.

\section{References}

Albert BM and Innes B (2019) On the distinction of pollen grains of early varieties of Hordeum from Glyceria species: Addressing the early cereal cultivation problem in Palynology. Palynology 44(2): 369-381.

Alcock L, Alcock EA and Driscoll ST (1989) Reconnaissance excavations on Early Historic fortifications and other royal sites in Scotland, 1974-84; 3. Excavations at Dundurn, Strathearn, Perthshire: 1976-77. Proceedings of the Society of Antiquaries of Scotland 119: 189-226.

Allen AJ and Anderson J (1903) The Early Christian Monuments of Scotland (Society of Antiquaries of Scotland), vol. 1-2. Edinburgh: Neill and Co. Ltd. Available at: https://archive. org/details/earlychristianmo12alle/mode/2up (accessed 10 September 2020).

Andersen ST (1979) Identification of wild grass and cereal pollen. Danmarks Geologiske Undersøegelse Arbog 1978: 69-92.

Anderson MO (2011) Kings and Kingship in Early Scotland, reprint of 2nd edn. Edinburgh: Birlinn.

Bakker M and Van Smeerdijk DG (1982) A Palaeoecological study of a late-Holocene section from "Het Ilperveld", Western Netherlands. Review of Palaeobotany and Palynology 36: 95-163.

Benovitz N (2014) The Justinianic plague: Evidence from the dated Greek epitaphs of Byzantine Palestine and Arabia. Journal of Roman Archaeology 27: 487-498. DOI: 10.1017/ S1047759414001378.

Berry R (2018) Environmental Attitudes through Time. Cambridge: Cambridge University Press, p.60.

Beug HJ (1961) Leitfaden der pollenbestimmung. Stuttgart: Gustav Fischer Verlag.

Beug HJ (2004) Leitfaden der pollenbestimmung für mitteleuropa und angrenzende gebiete. München: Verlag Dr. Friedrich Pfeil.

Birks HJB and Birks H (1980) Quaternary Palaeoecology. Baltimore, MD: University Park Press.

Bower W and Watt DER (1990) Scotichronicon by Walter Bower 1385-1449 (ed. Watt DER, Taylor S and Scott B), Books IX and X, vol. 5. Aberdeen: Aberdeen University Press.

Bradshaw JE, Gemmell DJ, Gower S et al. (2002) Turnip (Brassica rapa L. ssp. Rapifera Metzg.) population improvement and cultivar production. Plant Breeding 121: 301-306.

Bronk Ramsey C (2009a) Bayesian analysis of radiocarbon dates. Radiocarbon 51(1): 337-360.

Bronk Ramsey C (2009b) Dealing with outliers and offsets in radiocarbon dating. Radiocarbon 51(3): 1023-1045.

Bronk Ramsey C (2020) OxCal 4.2. Available at: https://c14.arch. ox.ac.uk/oxcal.html (accessed April 2020).

Bronk Ramsey C and Lee S (2013) Recent and planned developments of the program OxCal. Radiocarbon 55(2-3): 720-730.

Broun D (1999) The Irish Identity of the Kingdom of the Scots in the Twelfth and Thirteenth Centuries. Woodbridge: Boydell.
Brown AG, Carpenter RG and Walling DE (2007) Monitoring fluvial pollen transport, its relationship to catchment vegetation and implications for palaeoenvironmental studies. Review of Palaeobotany and Palynology 147(1-4): 60-76.

Caspermeyer J (2016) Reconstructing the sixth century plague from a victim. Molecular Biology and Evolution 33(11): 3028-3030.

Cheburkin AK and Shotyk W (1996) An energy-dispersive miniprobe multielement analyzer (EMMA) for direct analysis of $\mathrm{Pb}$ and other trace elements in peats. Fresenius Journal of Analytical Chemistry 354: 688-691.

Cook MJ (2013) Paradigms, assumptions, enclosure, and violence: The hillforts of Strathdon. Journal of Conflict Archaeology 8(2): 77-105.

Cook MJ, Cook ML and Humble J (2010) Hillforts of Strathdon Phase 4: Cairnmore. Edinburgh: Data Structure Report Prepared for RCAHMS.

Cool HEM (2006) Greengrocery. In:Cool HEM (ed.) Eating and Drinking in Roman Britain. Cambridge: Cambridge University Press, pp.119-128.

Cushing EJ (1967) Evidence for differential pollen preservation in Late Quaternary sediments in Minnesota. Review of Palaeobotany and Palynology 4: 87-101.

Delcourt PA and Delcourt HR (1980) Pollen preservation and Quaternary environmental history in the south-eastern United States. Palynology 4: 215-231.

Dennison PE, Ditchburn D and Lynch M (eds) (2002) Aberdeen before 1800 - A New History. East Lothian: City of Aberdeen Council, Tuckwell Press, p.74.

Dickson C (1987) Appendix 1.9: The macroscopic plant remains. In: Hedges JW, Bell B and Smith B (ed.) Bu, Gurness and the Brochs of Orkney. Part I: Bu. B.A.R. British Series 163. Oxford: British Archaeological Reports, pp.137-142.

Dickson C (1988) Distinguishing cereal from wild grass pollen: Some limitations. Circaea 5(2): 67-71.

Edwards KJ (1981) The separation of Corylus and Myrica pollen in modern and fossil samples. Pollen et Spores 23: 205-218.

Fægri K and Iversen J (1975) Textbook of Pollen Analysis, revised 3rd edn. New York: Hafner Press.

Fægri K, Kaland PE and Krzywinski K (1989) Textbook of Pollen Analysis, by Knut Fagri and Johs Iversen. Caldwell, NJ: The Blackburn Press.

Fitter R, Fitter A and Blamey M (1996) Collins Pocket Guide: Wildflowers of Britain and Northern Europe, 5th edn. Milan: Harper Collins Publishers.

Fraser JE (2009) From Caledonia to Pictland Scotland to 795. The New Edinburgh History of Scotland. Edinburgh: Edinburgh University Press.

Gallagher K, Bodin T, Sambridge M et al. (2011) Inference of abrupt changes in noisy geochemical records using transdimensional changepoint models. Earth and Planetary Science Letters 311: 182-194.

Gibbons A (2018) Eruption made 536 'the worst year to be alive'. Science 362(6416): 733-734. DOI: 10.1126/science.362.6416.733.

Gimmingham CH (1972) The Ecology of Heathlands. London: Chapman \& Hall.

Grimm EC (1991-2011) Tilia, Tilia Graph and TGView. Springfield, IL: Illinois State Museum. Available at: http://www.tiliait.com/ (accessed March 2019-2020).

Grimm EC and Jacobson GL Jr (2004) Late-quaternary vegetation history of the eastern United States. In: Gillespie AR, Porter SC and Atwater BF (eds) The Quaternary Period in the United States (Developments in Quaternary Science). Amsterdam: Elsevier, pp.381-402. 
Grimm EC, Maher LJ Jr and Nelson DM (2009) The magnitude of error in conventional bulk-sediment radiocarbon dates from central North America. Quaternary Research 72: 301-308.

Haaster H (1984) Een paleoecologisch onderzoek aan een vroegsubboreal veensectie uit de ongeving van Vinkeveen. $\mathrm{PhD}$ Thesis, aan de Vrije Universiteit (The Vrije University), Amsterdam.

Hall AR and Kenward HK (1990) Environmental Evidence from the Colonia: General Accident and Rougier Street (The Archaeology of York), vol. 14(6). London: Council for British Archaeology, pp.289-434.

Hall V (1989) A study of the modern pollen rain from a reconstructed 19th century farm. Irish Naturalists Journal 23: $82-92$.

Hall V (2000) The documentary and pollen analytical records of the vegetational records of the vegetational history of the Irish landscape AD 200-1650. Peritia 14: 342-371.

Halliday SP (2007) The later prehistoric landscape. In: RCAHMS (eds) In the Shadow of Bennachie: A Field Archaeology of Donside, Aberdeenshire. Edinburgh: RCAHMS \& Society of Antiquaries of Scotland, pp.79-114.

Hartley D (1954) Food in England. London: Macdonald.

Heiri O, Lotter AF and Lemcke G (2001) Loss on ignition as a method for estimating organic and carbonate content in sediments: Reproducibility and comparability of results. Journal of Paleolimnology 25: 101-110.

Hobbs RJ, Malik AU and Gimmgham CH (1984) Studies on fire in Scottish heathland communities. Journal of Ecology 72 : 963-976.

Joly C, Barillé L, Barreau M et al. (2007) Grain and annulus diameter as criteria for distinguishing pollen grains of cereals from wild grasses. Review of Palaeobotany and Palynology 146: 221-233.

Keller M, Spyrou MA, Scheib CL et al. (2019) Ancient Yersinia pestis genomes from across Western Europe reveal early diversification during the First Pandemic (541-750). Proceedings of the National Academy of Sciences 116 (25): 12363-12372. DOI: 10.1073/pnas.1820447116.

Kenicer G, Bridgewater S and Milliken W (2000) The ebb and flow of Scottish seaweed use. Botanical Journal of Scotland 52: 119-148.

Kołaczek P, Zubek S, Błaszkowski J et al. (2013) Erosion or plant succession - How to interpret the presence of arbuscular mycorrhizal fungi (Glomeromycota) spores in pollen profiles collected from mires. Review of Palaeobotany and Palynology 189: 29-37.

Kuhry P (1985) Transgression of a raised bog across a covers and ridge originally covered with an oak-lime forest. Palaeoecological study of a Middle Holocene local vegetation succession in the Amtsven (northwest Germany). Review of Palaeobotany and Palynology 44: 303-353.

Kuhry P (1997) The palaeoecology of a treed bog in western boreal Canada: A study based on microfossils, macrofossils and physico-chemical properties. Review of Palaeobotany and Palynology 96: 183-224.

Küttner A, Mighall TM, De Vleeschouwer F et al. (2014) A 3300year atmospheric metal contamination record from Raeburn Flow raised bog, south west Scotland. Journal of Archaeological Science 44: 1-11.

Kylander M, Bindler R, Martínez Cortizas A et al. (2013) A novel geochemical approach to paleorecords of dust deposition and effective humidity: 8500 years of peat accumulation at Store Mosse (the "Great Bog"), Sweden. Quaternary Science Reviews 69: 69-82.

Lewis S (1846) Renton - Ross \& Cromarty (Originally published in: A Topographical Dictionary of Scotland). London: British History Online, pp.416-430. Available at: https://www. british-history.ac.uk/topographical-dict/scotland/pp416430\#h3-0011 (accessed 24 May 2019).

Mighall TM, Foster ID, Rowntree KM et al. (2012) Reconstructing recent land degradation in the semi-arid Karoo of South Africa: A palaeoecological study at Compassberg, eastern Cape. Land Degradation and Development 23: 523-533.

Mitchell J and Noble G (2017) The monumental cemeteries of northern Pictland. Medieval Archaeology 61: 1-40.

Moore PD, Webb JA and Collinson ME (1991) Pollen Analysis. London: Blackwell Scientific.

Muller J, Kylander M, Martínez-Cortizas A et al. (2008) The use of principle component analyses in characterising trace and major elemental distribution in a $55 \mathrm{kyr}$ peat deposit in tropical Australia: Implications to paleoclimate. Geochimica Cosmochimica Acta 72: 449-463.

Murphy P (1979) Hascombe: Carbonised cereals and crop weeds. In: Thompson F. Three Surrey Hillforts: Excavations at Anstiebury, Holmbury, and Hascombe, 1972-1977. The Antiquaries Journal 59(2): 245-318.

Nakagawa T, Brugiapaglia E, Digerfelt G et al. (1998) Densemedia separation as a more efficient pollen extraction method for use with organic sediment/deposit samples: Comparison with the conventional method. Boreas 27: 15-24.

National Library of Scotland (2019) Aberdeenshire, Sheet XLIII (includes: Auchindoir and Kearn; Clatt; Kennethmont; Leslie, Survey date: 1866, publication date: 1870). Available at: https://maps.nls.uk/view/74425345 (accessed September 2019).

National Soil Map of Scotland (2020) Series Glaschul (58815); Series Countesswells (10213); Series Boyndie (07223). Scottish Government Licence Number 100020540. Available at: http://map.environment.gov.scot/Soil_maps/?layer=1 (accessed January 2020).

NBNatlas (2021) Valsaria. Available at: https://records.nbnatlas. org/occurrences/a03affb8-3dbe-4c04-843b-9c4520c9ccdb (accessed February 2021).

Noble G and Evans N (2019) The King in the North: The Pictish Realms of Fortriu and Ce. Edinburgh: Birlinn Ltd.

Noble G, Gondek M, Campbell E et al. (2013) Between prehistory and history: The archaeological detection of social change among the Picts. Antiquity 87: 1136-1150.

Noble G, Gondek M, Campbell E et al. (2019a) A powerful place of Pictland: Interdisciplinary perspectives on a power centre of the 4th to 6th centuries ad. Medieval Archaeology 63(1): $56-94$.

Noble G, Lamont P and Masson-Maclean E (2019b) Assessing the ploughzone: The impact of cultivation on artefact survival and the cost/benefits of topsoil stripping prior to excavation. Journal of Archaeological Science Reports 23: 549-558.

Noble G, Maclver C, O'Driscoll J et al. (2019c) Cairnmore (Data Structure Report). Aberdeen: University of Aberdeen (Unpublished report).

Noble G, Maclver C, O'Driscoll J et al. (2019d) Excavations at Tap O'Noth 2019 (Data Structure Report). Aberdeen: University of Aberdeen (Unpublished report).

Page CN (1997) The Ferns of Britain and Ireland, 2nd edn. Cambridge: Cambridge University Press.

Pals JP, Van Geel B and Delfos A (1980) Paleoecological studies in the Klokkeweel bog near Hoogkarspel (Noord Holland). Review of Palaeobotany and Palynology 30: 371-418.

Ralston I and Watt W (1981) Tap o' Noth. In: Proudfoot EVW (ed.) Discovery and Excavation in Scotland. Fife, Scotland: Council for British Archaeology, p.14.

Ralston I and Watt W (1982) Tap o' Noth. In: Proudfoot EVW (ed.) Discovery and Excavation in Scotland. Fife, Scotland: Council for British Archaeology, p.12. 
Ralston I and Watt W (1983) Tap o' Noth. In: Proudfoot EVW (ed.) Discovery and Excavation in Scotland. Fife, Scotland: Council for British Archaeology, p.10.

Ramsay S (2019) Excavation of a palisaded and ditched enclosure and timber buildings in association with the Craw Stane, Rhynie, Aberdeenshire: Archaeobotanical report. (Unpublished material).

Reille M (1999) Pollen et spores d'Europe et d'Afrique du nord. Marseille: Laboratoire de Botanique Historique et Palynologie.

Reimer P, Austin WEN, Bard E et al. (2020) The IntCal20 Northern Hemisphere radiocarbon age calibration curve $(0-55$ cal kB). Radiocarbon 62: 725-757. DOI: 10.1017/RDC.2020.41.

Reimer PJ, Bard E, Bayliss A et al. (2013) IntCal13 and Marine13 radiocarbon age calibration curves $0-50,000$ years cal BP. Radiocarbon 55(4): 1869-1887.

Rice CM and Ashcroft WA (2003) The geology of the northern half of the Rhynie Basin, Aberdeenshire, Scotland. Transactions of the Royal Society of Edinburgh: Earth Sciences 94: 299-308.

Riddet WM (1925) Turnip crop. In: Paterson WGR (ed.) Farm Crops, Volume II Root Crops. London: Gresham Publishing Co. Ltd, pp.69-118.

Rodwell JS (1995) British Plant Communities. vol. 4, Aquatic Communities, Swamps and Tall-Herb Fens. Cambridge: Cambridge University Press.

Ross AD (2003) The Province of Moray, c.1000-1230, 2 vols. Unpublished $\mathrm{PhD}$ Thesis, University of Aberdeen, Aberdeen.

Schofield JE, Edwards JJ, Mighall TM et al. (2010) An integrated geochemical and palynological study of human impacts, soil erosion and storminess from southern Greenland since c. AD 1000. Palaeogeography, Palaeoclimatology, Palaeoecology 295: 19-30.

Scotlands Places (2019) Farm horse tax roll 1797-1798, vol. 7. Available at: https://scotlandsplaces.gov.uk/digital-volumes/ historical-tax-rolls/farm-horse-tax-rolls-1797-1798/farmhorse-tax-1797-1798-volume-07/50 (accessed October 2019).

Shepherd C (2018) A 12th century 'bowl-fired' grain-drying kiln at Druminnor Castle, Aberdeenshire. Implications for Social change, agricultural productivity and landscape development in north-east Scotland. Studia Celtica 52: 1-32.

Shore JS, Bartley DD and Harkness DD (1995) Problems encountered with the $14 \mathrm{C}$ dating of peat. Quaternary Science Reviews 14(4): 373-383.

Shotyk W (1988) Review of the inorganic geochemistry of peats and peatland waters. Earth Science Reviews 25: 95-176.

Simpson WD (1922) The architectural history of Huntly Castle. Proceedings of the Society of Antiquaries of Scotland 56: 134-163.

Simpson WD (1930) Craig castle and the kirk of Auchindoir, Aberdeenshire. Proceedings of the Society of Antiquaries of Scotland 64: 48-96.

Skene FJH (1872) John of Fordun's chronicle of the Scottish nation. In: Skene WF (ed.) The Historians of Scotland, vol 4. Edinburgh: Edmonston and Douglas, pp.1-46.

Spooner BM (1986) New or rare British microfungi from Esher Common, Surrey. Transactions of the British Mycological Society 86(3): 401-408.

Stace C (2010) New Flora of the British Isles, 3rd edn. Cambridge: Cambridge University Press.
Stuiver M, Reimer PJ and Reimer RW (2020) CALIB 8.2 [WWW program]. Available at: http://calib.org (accessed September 2020).

Taboada T, Martínez-Cortizas A, García C et al. (2006) Particle-size fractionation of titanium and zirconium during weathering and pedogenesis of granitic rocks in NW Spain. Geoderma 131(12): $218-236$.

The New Statistical Accounts of Scotland 1791-1845 (NSA) (1845) Rhynie, county of Aberdeen, NSA, vol. 12. Available at: https://stataccscot.edina.ac.uk/static/statacc/dist/viewer/ nsa-vol12-Parish_record_for_Rhynie_in_the_county_of_ Aberdeen_in_volume_12_of_account_2/ (accessed February 2020).

The Old Statistical Accounts of Scotland 1791-1845 (OSA) (1794) Forbes and Kearn, county of Aberdeen, OSA, vol. 11. Available at: https://stataccscot.edina.ac.uk/static/statacc/dist/ viewer/osa-vol11-Parish_record_for_Forbes_and_Kearn_in the_county_of_Aberdeen_in_volume_11_of_account_1/osavol11-p189-parish-aberdeen-forbes_and_kearn? ${ }_{-}$search $=$kearn (accessed February 2020).

The Old Statistical Accounts of Scotland 1791-1845 (OSA) (1797) Rhynie, county of Aberdeen, OSA, vol. 19. Available at: https://stataccscot.edina.ac.uk/static/statacc/dist/viewer/ osa-vol19-Parish_record_for_Rhynie_in_the_county_of Aberdeen_in_volume_19_of_account_1/ $\overline{\text { (accessed Febru- }}$ ary 2020).

Tipping RM (1987) The origins of corroded pollen grains at five early postglacial pollen sites in western Scotland. Review of Palaeobotany and Palynology 53: 151-161.

Tweddle J, Edwards K and Fieller N (2005) Multivariate statistical and other approaches for the separation of cereal from wild Poaceae pollen using a large Holocene dataset. Vegetation History and Archaeobotany 14: 15-30.

Van der Veen M, Livarda A and Hill A (2008) New plant foods in Roman Britain-dispersal and social access. Environmental Archaeology 13(1): 11-36.

Van der Wiel AM (1983) A palaeoecological study of a section from the foot of the hazendonk (Zuid-Holland, the Netherlands), based on the analysis of pollen, spores and macroscopic plant remains. Review of Palaeobotany and Palynology 38: 35-90.

Van Geel B (1976) A Palaeoecological Study of Holocene Peat Bog Sections Based on the Analysis of Pollen, Spores and Macro- and Microscopic Remains of Fungi, Algae, Cormophytes and Animals. Amsterdam: Academisch proefschrift. Huego de Vries laboratorium. Universiteit van Amsterdam.

Van Geel B (1978) A palaeoecological study of Holocene peat bog sections in Germany and the Netherlands, based on the analysis of pollen, spores and macro- and microscopic remains of fungi, algae, cormophytes and animals. Review of Palaeobotany and Palynology 25: 1-120.

Van Geel B (2006) Non-pollen palynomorphs. In: Smol JP, Birks HJB and Last WM (eds) Tracking Environmental Change using Lake Sediment Volume 3: Terrestrial, Algal and Siliceous Indicators. Dordrecht: Kluwer Academic Publishers, pp.99-120.

Van Geel B, Bohncke SJP and Dee H (1981) A palaeoecological study of an upper Late Glacial and Holocene sequence from "De Borchert", The Netherlands. Review of Palaeobotany and Palynology 31: 367-448. 
Van Geel B, Buurman J, Brinkkemper O et al. (2003) Environmental reconstruction of a Roman period settlement site in uitgeest (The Netherlands), with special reference to coprophilous fungi. Journal of Archaeological Science 30: 873-883.

Van Geel B, Hallewas DP and Pals JP (1983) A Late-Holocene deposit under the Westfriese Zeedijk near Enkhuizen (Prov. Of N-Holland, the Netherlands): Palaeoecological and archaeological aspects. Review of Palaeobotany and Palynology 38: 269-335.

Van Geel B, Klink AG, Pals JP et al. (1986) An upper Eemian lake deposit from Twente, eastern Netherlands. Review of Palaeobotany and Palynology 47: 31-61.
Weiss D, Shotyk W, Cheburkin AK et al. (1998) Determination of $\mathrm{Pb}$ in the ash fraction of plants and peats using the energydispersive Miniprobe Multielement Analyser (EMMA). Analyst 123: 2097-2102.

Woolf A (2006) Dun Nechtain, Fortriu and the geography of the Picts. Scottish Historical Review 85(2): 182-201.

Woolf A (2007) From Pictland to Alba: 789-1070. Edinburgh: Edinburgh University Press.

Young M and Hamilton S (2017) X-ray Fluorescence Analysis of Selected Crucibles and Moulds from the Rhynie Assemblage June 2017 (Data Structure Report). Edinburgh: Historic Environment Scotland. 